\title{
1 An anti-diuretic hormone receptor in the human disease \\ 2 vector, Aedes aegypti: identification, expression analysis \\ 3 and functional deorphanization
}

5 Authors:

6 Farwa Sajadi, Ali Uyuklu, Christine Paputsis, Aryan Lajevardi, Azizia Wahedi, Lindsay Taylor Ber,

7 Andreea Matei and Jean-Paul V. Paluzzi*

8

9 Affiliation:

10 Department of Biology, York University, 4700 Keele Street, Toronto, Ontario, M3J 1P3, Canada.

11

12 * Corresponding Author:

13 E-mail: paluzzi@yorku.ca

14 Phone: (416) 736-2100 ext. 20999

15 Lumbers Building, Room 221

16 Department of Biology, York University,

174700 Keele Street, Toronto, Ontario, M3J 1P3, Canada.

18

\section{$\underline{\text { Keywords: }}$}

20 CAPA; CAP2b; G protein-coupled receptor; Malpighian tubules; anti-diuresis; $\mathrm{DH}_{31}$; mosquito natriuretic

21 hormone 


\section{Significance}

25 Insects are by far the most successful and abundant group of organisms on earth. As a result of their small

26 size, insects have a relatively large surface area to volume ratio, raising the potential for rapid gain or loss

27 of water, ions and other molecules including toxins - a phenomenon that applies to insects living in both

28 aquatic and terrestrial environments. In common with many other organisms, hormones are key regulators

29 of the excretory system in insects, and numerous factors control the clearance of excess water and ions

30 (i.e. diuretics) or retention of these elements (i.e. anti-diuretics). Here we characterized an endogenous

31 anti-diuretic hormone receptor in the human disease vector, Aedes aegypti, demonstrating its expression is

32 highly enriched in the Malpighian 'renal' tubules and is necessary for eliciting anti-diuretic control of this

33 key component of the mosquito excretory system. 
$\underline{\text { Abstract }}$

Insect CAPA neuropeptides, which are homologs of mammalian neuromedin $\mathrm{U}$, have been described in various insect species and are known to influence ion and water balance by regulating the activity of the Malpighian 'renal' tubules (MTs). A number of diuretic hormones have been shown to increase primary fluid and ion secretion by the insect MTs and, in the adult female mosquito, a calcitonin-related peptide

$41\left(\mathrm{DH}_{31}\right)$ also known as mosquito natriuretic peptide, increases sodium secretion at the expense of

42 potassium to remove the excess salt load acquired upon blood-feeding. An endogenous mosquito anti-

43 diuretic hormone was recently described, having inhibitory activity against select diuretic factors and

44 being particularly potent against $\mathrm{DH}_{31}$-stimulated diuresis. In the present study, we have functionally

45 deorphanized, both in vitro and in vivo, a mosquito anti-diuretic hormone receptor (AedaeADHr).

46 Expression analysis by quantitative PCR indicates the receptor is highly enriched in the MTs, and

47 fluorescent in situ hybridization confirms expression within principal cells. Characterization using a

48 heterologous system demonstrated the receptor was highly sensitive to mosquito CAPA peptides. In adult

49 females, AedaeADHr transcript knockdown using RNAi led to the abolishment of CAPA-peptide induced

50 anti-diuretic control of $\mathrm{DH}_{31}$-stimulated MTs. The neuropeptidergic ligand is produced within a pair of

51 neurosecretory cells in each of the six abdominal ganglia, whose axonal projections innervate the

52 abdominal neurohaemal organs (known as the perivisceral organs), where these neurohormones are

53 released into the open circulatory system of the insect. Furthermore, pharmacological inhibition of

54 PKG/NOS signalling abolished the anti-diuretic activity of AedaeCAPA-1, which collectively confirms

55 the role of cGMP/PKG/NOS in this anti-diuretic signalling pathway. 


\section{$\underline{\text { Introduction }}$}

Neuropeptides are central regulators of behaviours and control a plethora of physiological processes in all eukaryotic organisms. Insects, like many other animals, contain a comprehensive repertoire of neuropeptides along with their cognate receptors, which are essential for controlling complex biological phenomena including circadian rhythms, diapause, development, reproduction, pheromone

61 biosynthesis, metabolism, circulation, stress as well as hydromineral balance ${ }^{1-10}$. Insects have a high

62 surface area to volume ratio, which has implications for their ability to maintain levels of water and ions

63 within a normal homeostatic range. In order to ensure their survival, most insects have a relatively

64 'simple' excretory system comprised of the Malpighian 'renal' tubules (MTs) and hindgut (ileum and

65 rectum). The MTs produce the primary urine acting to clear the haemolymph of excess ions, metabolites

66 and toxins while the hindgut generally functions in reabsorptive processes eliminating any unintentional

67 loss of essential ions and amino acids ${ }^{11,12}$. The insect excretory system is under complex control, which

68 may include direct innervation and regulation by neurotransmitters such as proctolin, as observed in the

69 hindgut of many insects ${ }^{13,14}$. The excretory system in insects is also under the control by various

70 circulating hormones ${ }^{15,16}$, which is the sole mechanism of extrinsic control in the non-innervated MTs,

71 while endocrine factors may also influence the hindgut ${ }^{4}$.

The overwhelming majority of studies investigating regulators of the insect excretory system

73 have focused on diuretic regulators of the $\mathrm{MTs}^{17-25}$, with only a few studies characterizing factors

74 responsible for controlling reabsorptive processes across hindgut epithelia ${ }^{12,26-30}$. In addition, a few anti-

75 diuretic factors that inhibit primary urine secretion by the insect MTs have also been reported ${ }^{31-36}$, acting

76 to counter the activity of the diuretic hormones that increase ion and water secretion rates. We recently

77 identified an endogenous anti-diuretic hormone in the disease-vector mosquito, Aedes aegypti, that

78 strongly inhibits select diuretic factors including the mosquito natriuretic peptide (a calcitonin-related

79 diuretic hormone $)^{37}$, which is critical for the post-prandial sodium-rich diuresis that follows blood gorging

80 by adult females ${ }^{22}$. Similarly, anti-diuretic activity of CAPA neuropeptides has been reported earlier in 
81 larval A. aegypti $^{36}$ as well as in other insects ${ }^{31,38-42}$, with signalling involving cGMP as a second

82 messenger ${ }^{31,37,40,42,43}$. In addition to their clear anti-diuretic roles, CAPA peptides have also been linked to

83 desiccation, where desiccation stress in Drosophila melanogaster leads to upregulation of capa mRNA,

84 which is suggested to elevate CAPA levels in the $\mathrm{CNS}^{44}$. In many insects, CAPA peptides act through a

85 conserved nitridergic signalling pathway leading to increased fluid secretion by MTs ${ }^{44,24}$. The mosquito

86 anti-diuretic hormone is a member of the CAPA peptide family, which along with other insect PRXamide

87 peptides, share homology to the vertebrate neuromedin U peptides ${ }^{45}$. CAPA neuropeptides are most

88 abundant in specialized neurosecretory ventral abdominal (Va) neurons ${ }^{46-49}$ of the abdominal ganglia (or

89 in the analogous neuromeres in insects with fused abdominal ganglia) ${ }^{50,51}$ and stored within abdominal

90 perivisceral organs ${ }^{52-55}$, which are major neurohaemal organs facilitating neurohormone release into

91 circulation for delivery to target organs expressing receptors.

In the present study, we utilized a combination of molecular tools, heterologous functional assays,

93 physiological bioassays and reverse genetics techniques to identify and unravel the functional role of an

94 anti-diuretic hormone receptor in the disease-vector mosquito, A. aegypti. Our data provides further

95 evidence that mosquito CAPA neuropeptides, together with their cognate receptor identified herein,

96 function in a neuroendocrine system halting the stimulatory activity of diuretic hormones that, if left

97 unregulated, may compromise ion and water homeostasis in this important anthropophilic mosquito. 
99 Animals and dissections. Various stages of $A$. aegypti (Liverpool strain) were obtained from a laboratory

100 colony maintained as described previously ${ }^{56}$. All mosquitoes were raised under a 12:12 light-dark cycle

101 regime. Whole insects at each post-embryonic stage were used for examining developmental expression

102 profiles and dissected tissues and organs were isolated from adults of each sex that were four-days post-

103 eclosion. Adults were immobilized with brief exposure to carbon dioxide and then dissected to isolate

104 individual organs using fine forceps (Fine Science Tools, North Vancouver, British Columbia, Canada)

105 under nuclease-free Dulbecco's phosphate-buffered saline (DPBS) at room temperature (RT).

106 Immunohistochemistry. The dissected tissues/organs were fixed overnight at $4{ }^{\circ} \mathrm{C}$ with $4 \%$

107 paraformaldehyde prepared in DPBS and were then washed several times with DPBS to remove fixative.

108 The tissues were subsequently permeabilized in $4 \%$ Triton X-100, 10\% normal sheep serum (NSS) and

$1092 \%$ bovine serum albumin (BSA) prepared in DPBS and incubated for 1 hour at RT on a rocking platform

110 and then washed several times with DPBS to remove any traces of the permeabilization solution. The

111 primary antibody was prepared using a custom affinity-purified rabbit polyclonal antibody (Genscript,

112 Piscataway, NJ) produced against Rhodnius prolixus RhoprCAPA-2 (EGGFISFPRV-NH 2 ; a kind gift

113 from Prof. Ian Orchard, University of Toronto), which was diluted in 0.4\% Triton X-100 containing 2\%

114 NSS and 2\% BSA in DPBS. The stock antibody was diluted 1:1000 for stand-alone

115 immunohistochemistry; however, when fluorescence in situ hybridization (FISH) preceded

116 immunohistochemistry, the antibody was diluted 1:500 in the aforementioned solution. Tissues were

117 incubated in the primary antibody solution for 48 hours at $4^{\circ} \mathrm{C}$ on a rocking platform, and no primary

118 controls were incubated in the same solution of $0.4 \%$ Triton X-100 containing $2 \%$ BSA and $2 \%$ NSS in

119 DPBS, but lacking primary antibody. After the primary antibody incubation, tissues were washed three

120 times for one hour each with DPBS at RT. The secondary antibody solution was prepared using either

121 FITC-conjugated sheep anti-rabbit immunoglobulin G (Jackson ImmunoResearch Laboratories, West

122 Grove, PA) or Alexa Fluor 488-conjugated cross-adsorbed goat anti-rabbit immunoglobulin G (Life 
123 Technologies, Burlington, ON) diluted 1:200 in DPBS containing 10\% NSS. The tissues were incubated

124 in the secondary antibody solution overnight at $4^{\circ} \mathrm{C}$ on a rocking platform and were then washed with

125 DPBS several times at RT. Tissues were mounted in ProLong Diamond Antifade Mountant containing

126 DAPI (Molecular Probes, Eugene, OR) onto microscope slides and analyzed using a Lumen Dynamics

127 XCite ${ }^{\mathrm{TM}}$ 120Q Nikon fluorescence microscope (Nikon, Mississauga, ON, Canada) or EVOS FL Auto

128 Live-Cell Imaging System (Life Technologies, Burlington, ON).

Determination of the complete cDNA of an A. aegypti anti-diuretic hormone receptor.

130 The Anopheles gambiae CAPA receptor identified previously $y^{57}$ was used as a query for Megablast

131 screening of the A. aegypti genomic scaffold database available locally on a lab computer running

132 Geneious ${ }^{\circledR}$ 6.1.8 (Biomatters Ltd, Auckland, New Zealand) and the highest scoring hits (mapping within

133 supercontig1.1) were assembled and predicted introns were excised. Using the Primer3 module in

134 Geneious ${ }^{\circledR}$ 6.1.8, gene-specific oligonucleotides targeting this region (see Table S1) were designed to

135 amplify this predicted partial fragment using Q5 High Fidelity DNA Polymerase (New England Biolabs,

136 Whitby, On) with whole adult female A. aegypti cDNA as template. The PCR product was purified, A-

137 tailed, cloned into pGEM-T vector (Promega, Madison, WI, USA) and nucleotide sequence was

138 confirmed by Sanger sequencing (Center for Applied Genomics, Hospital for Sick Children, Toronto,

139 ON). After successful validation of the cloned partial sequence, primers were designed (as described

140 above) to perform 5' and $3^{\prime}$ rapid amplification of cDNA ends (RACE)-PCR utilizing the Clontech

141 SMARTer 5'/3' RACE Kit (Takara BIO USA Inc, CA, USA) as recently described ${ }^{58}$. To facilitate cloning

142 of amplicons, the linker sequence GATTACGCCAAGCTT, which overlaps with the pRACE vector

143 provided in the RACE kit, was added to the 5' ends of the gene-specific primers (Table 1). First-strand

144 cDNA synthesis was prepared using $1 \mu \mathrm{g}$ total RNA from whole adult female mosquitoes using the $3^{\prime}$

145 CDS primer (provided in the kit) and a gene-specific reverse primer to generate template cDNA for 5 '

146 RACE. Nested PCR reactions utilized gene-specific forward (3' RACE) and reverse (5' RACE) primers

147 (see Table S1) and a universal primer mix (UPM) to amplify the complete cDNA encoding A. aegypti 
CAPAr with optimal cycling parameters determined empirically. Specifically, for both 5' and 3' RACE this included an initial denaturation at $94 \square{ }^{\circ} \mathrm{C}$ for $1 \square \mathrm{min}$, followed by 40 cycles of $30 \square \mathrm{s}$ at $94 \square{ }^{\circ} \mathrm{C}, 30 \square \mathrm{s}$ at $68 \square{ }^{\circ} \mathrm{C}$, and $3 \square \min$ at $72 \square{ }^{\circ} \mathrm{C}$ to amplify PCR products using SeqAmp DNA Polymerase. Following

151 three rounds of nested PCR amplification using gene-specific primers, the amplicons were separated on a

$1521 \%$ agarose gel, extracted and cloned into the linearized pRACE vector. Plasmid DNA was isolated using

153 a Monarch plasmid miniprep kit (New England Biolabs, Whitby, ON) and several clones were sent for

154 sequencing for sequence validation. Finally, primers were designed at the $5^{\prime}$ and $3^{\prime}$ ends of the complete

155 cDNA sequence (including UTRs) and used for final PCR amplification of the full receptor cDNA with

156 Q5 High Fidelity DNA polymerase to confirm base pair accuracy.

\section{Heterologous receptor functional activation bioluminescence assay. The open reading frame of the}

158 cloned A. aegypti CAPAr was inserted into pcDNA3.1+ mammalian expression vector following

159 procedures described previously ${ }^{58-60}$. Using a recombinant CHO-K1 cell line stably expressing aequorin ${ }^{61}$,

160 A. aegypti CAPAr was transiently expressed following growth and transfection conditions as reported

161 recently ${ }^{58}$. Cells were harvested for the functional assay at 48 hours post-transfection by detaching cells

162 from the culture flask using 5mM EDTA in Dulbecco's PBS (DPBS; Wisent Corp., St. Bruno, QC) and

163 later cells were resuspended at a concentration of $10^{6}-10^{7}$ cells $/ \mathrm{mL}$ in assay media and incubated with

164 coelenterazine $h$ as described previously ${ }^{60}$. Prior to running the functional assay, cells were diluted 10-

165 fold in assay media and left to incubate for one additional hour. Several endogenous as well as other

166 insect neuropeptides representing a variety of neuropeptide families (see Table S2) were tested by

167 preparing serial dilutions of each peptide in assay media. All peptides were commercially synthesized at a

168 purity of $>90 \%$ (Genscript, Piscataway, $\mathrm{NJ}$ ) and $1 \mathrm{mM}$ stock solutions were prepared by dissolving $1 \mathrm{mg}$ of

169 each peptide in water or DMSO as appropriate based on specific peptide characteristics. Recombinant

170 CHO-K1 cells expressing the A. aegypti CAPAr were loaded into each well of multi-well plate using an

171 automated injector module linked to a Synergy 2 Multi Mode Microplate Reader (BioTek, Winooski, VT)

172 which measured kinetic luminescent response from each well for $20 \mathrm{sec}$ immediately following cell 
173 loading onto the different peptides at various doses. Data was compiled in Microsoft Excel and analyzed

174 in GraphPad Prism 8.0 (GraphPad Software, San Diego, CA).

175 RNA probe template preparation. To obtain a template for synthesizing DIG-labelled RNA probes for

176 use in FISH, a 373bp fragment of the A. aegypti CAPA partial mRNA (GenBank Accession:

177 XM_001650839) previously described ${ }^{50}$ and a 743bp product of the anti-diuretic hormone receptor

178 identified herein with primers designed (see Table S3) using the Primer3 plugin in Geneious® 6.1.8

179 (Biomatters Ltd., Auckland, New Zealand) were amplified using standard Taq DNA Polymerase (New

180 England Biolabs, Whitby, ON) following manufacturer- recommended conditions. PCR products were

181 column-purified with PureLink Quick PCR Purification Kit (Life Technologies, Burlington, ON) and

182 amplified in a subsequent PCR reaction to generate cDNA products with incorporated T7 promoter

183 sequence (see Table S1) to facilitate in vitro RNA synthesis of anti-sense or sense probes. The final

184 purified PCR products for use as templates for RNA probe synthesis were quantified on a SYNERGY 2

185 Microplate reader (Biotek, Winooski, VT).

Digoxigenin (DIG)-labelled RNA probe synthesis. PCR templates generated as described above (see

Table S3) were used for in vitro transcription reactions using the HiScribe T7 RNA Synthesis Kit (New

England Biolabs, Whitby, ON) following the recommended conditions when using modified nucleotides. separate analog (digoxigenin-11-UTP) or in a pre-mixed 10x DIG- RNA labelling mix (Sigma-Aldrich,

191 Oakville, ON). Template DNA was removed following treatment with RNase-free DNase I (New

192 England Biolabs, Whitby, ON) and an aliquot of the synthesized RNA probes were then visually assessed 193 using standard agarose gel electrophoresis and quantified on a SYNERGY 2 Microplate reader (Biotek,

194 Winooski, VT).

195 Fluorescence in situ Hybridization (FISH). An optimized FISH procedure based on a protocol 196 described previously for $R$. prolixus ${ }^{62,63}$ was utilized involving peroxidase-mediated tyramide signal 
amplification to localize cells expressing either the CAPA peptide mRNA or the anti-diuretic hormone receptor (CAPAr) mRNA. Tissues/organs were dissected under nuclease-free Dulbecco's phosphatebuffered saline (DPBS; Wisent, St. Bruno, QC) and were immediately placed in microcentrifuge tubes containing freshly-prepared fixation solution (4\% paraformaldehyde prepared in DPBS) and fixed for 1-2 hours at RT or overnight at $4^{\circ} \mathrm{C}$ on a rocker. Tissues/organs were subsequently washed five times with 0.1\% Tween-20 in DPBS (PBT) and treated with 1\% $\mathrm{H}_{2} \mathrm{O}_{2}$ (diluted in DPBS) for 10-30 minutes at RT to quench endogenous peroxidase activity. Tissues/organs were then incubated in 4\% Triton X-100 (Sigma

Aldrich, Oakville, ON) in PBT for 1 hour at RT to permeabilize the tissues and then washed with copious PBT. A secondary fixation of the tissues/organs was performed for 20 minutes in $4 \%$ paraformaldehyde in DPBS and then washed using PBT to remove all traces of fixative. The tissues/organs were then rinsed in a 1:1 mixture of PBT-RNA hybridization solution ( $50 \%$ formamide, $5 x \mathrm{SSC}, 0.1 \mathrm{mg} / \mathrm{mL}$ heparin, 0.1 $\mathrm{mg} / \mathrm{mL}$ sonicated salmon sperm DNA and $0.1 \%$ Tween-20) which was then replaced with RT RNA hybridization that had been prepared earlier by denaturing in a boiling water bath for five minutes and subsequently cooled on ice for five minutes. The samples were then incubated at $56^{\circ} \mathrm{C}$ for $1-2$ hours,

211 which served as the pre-hybridization treatment. During the pre-hybridization incubation, labelled RNA

212 probe (anti-sense for experimental or sense for control) was added to pre-boiled RNA hybridization

213 solution (2-4ng/uL final concentration) and this mixture was heated at $80^{\circ} \mathrm{C}$ for 3 minutes to denature the 214 single-stranded RNA probes and then cooled on ice for 5 minutes. The samples were then incubated 215 overnight in this hybridization solution containing the DIG-labelled RNA probe at $56^{\circ} \mathrm{C}$. The following 216 day, samples were washed twice with fresh hybridization solution (minus probe) and subsequently with $2173: 1,1: 1$ and 1:3 (vol/vol) mixtures of hybridization solution-PBT (all pre-warmed to $\left.56^{\circ} \mathrm{C}\right)$. The tissues 218 were subsequently washed with PBT pre-warmed to $56^{\circ} \mathrm{C}$ and in the final wash step were left to 219 equilibrate to RT. Next, to reduce non-specific staining, samples were blocked with PBTB (DPBS, $0.1 \%$ 220 Tween-20, 1\% Molecular Probes block reagent; Invitrogen, Carlsbad, CA) for one hour. Tissues/organs 221 were then incubated with a mouse anti-DIG biotin-conjugated antibody (Jackson ImmunoResearch 222 Laboratories, West Grove, PA) diluted 1:400 and incubated for 1.5hrs at RT on a rocker in the dark. The 
antibody solution was then removed and tissues were subjected to several washes in PBTB over the course of one hour. Tissues/organs were then incubated with horseradish peroxidase-streptavidin conjugate (Molecular Probes, Eugene, OR) diluted 1:100 in PBTB for 1 hour and the tissues were once again washed with PBTB several times over the course of an hour. Finally, prior to treatment with tyramide solution for the signal amplification of the target mRNA transcripts, samples were washed twice with PBT and once with DPBS. Afterwards, a tyramide solution was prepared consisting of Alexa Fluor 568 (or Alexa Fluor 647) tyramide dye in amplification buffer containing $0.015 \% \mathrm{H}_{2} \mathrm{O}_{2}$. After experimenting with various dilutions of the labeled tyramide, a 1:100 and 1:500 dilution of tyramide dye gave optimal results with minimal background staining for the ganglia and MTs, respectively. After the

232 last DPBS wash was removed from the tissues/organs, the tyramide solution was added and the tissues 233 were incubated in the dark for 1 hour on a rocker at RT. The tyramide solution was then removed and the 234 samples were washed with DPBS several times over the course of an hour. The tissues/organs were stored 235 in DPBS overnight at $4^{\circ} \mathrm{C}$ and then mounted on cover slips with mounting media comprised of DPBS 236 with $50 \%$ glycerol containing $4 \mu \mathrm{g} / \mathrm{mL} 4 \square, 6$ - diamidino-2-phenylindole dihydrochloride (DAPI). For 237 preparations involving transcript and neuropeptide co-detection in the nervous system, following the 238 tyramide treatment, neural tissues were washed several times with DPBS and then incubated with primary 239 antibody following the immunohistochemistry protocol described above. Tissues/organs were analyzed 240 using a Lumen Dynamics XCite ${ }^{\mathrm{TM}}$ 120Q fluorescence microscope (Nikon, Mississauga, ON, Canada) or 241 EVOS FL Auto Live-Cell Imaging System (Life Technologies, Burlington, ON).

\section{Synthesis of dsRNA for RNA interference and RT-qPCR. Double-stranded RNA (dsRNA) was}

243 synthesized and column-purified using the MEGAscript@ RNAi Kit (Invitrogen, Carlsbad, CA) following

244 the recommended protocol using primers for dsCAPAr synthesis (see Table S3) and primers as reported 245 previously for $\mathrm{dsARG}^{64}$, which is an ampicillin resistance gene cloned from standard sequencing plasmid 246 (pGEM T-Easy) that served as a negative control. A Nanoject Nanoliter Injector (Drummond Scientific,

247 Broomall, PA) was used to inject one-day old female mosquitoes with $1 \mu \mathrm{g}$ (in $\sim 140 \mathrm{~nL}$ ) of either 
dsCAPAR or dsARG. After injection, mosquitoes were recovered in a photo period-, temperature- and humidity-controlled incubator. Total RNA was then isolated from four-day old whole female mosquitoes injected with dsCAPAr or dsARG using the Monarch Total RNA Miniprep Kit (New England Biolabs,

251 Whitby, ON, Canada) and used as template (500ng) for cDNA synthesis using the iScript ${ }^{\mathrm{TM}}$ Reverse

252 Transcription Supermix (Bio-Rad, Mississauga, ON, Canada) following recommended guidelines diluting

253 cDNA ten-fold prior to quantitative RT-PCR. AedaeCAPAr and AedaeCAPA transcript levels were

254 quantified using gene-specific primers that were positioned on different exons (see Table S3) and

255 PowerUP' ${ }^{\mathrm{TM}}$ SYBR ${ }^{\circledR}$ Green Master Mix (Applied Biosystems, Carlsbad, CA, United States) and measured

256 on a StepOnePlus Real-Time PCR System (Applied Biosystems, Carlsbad, CA, United States) following

257 conditions described previously ${ }^{59}$. A similar procedure for cDNA synthesis and transcript quantification

258 as outlined above was followed for total RNA isolated from each post-embryonic developmental stage

259 and tissues/organs dissected from adult stage mosquitoes. Relative expression levels were determined

260 using the $\Delta \Delta \mathrm{Ct}$ method and were normalized to the geometric mean of $r p 49$ and $r p s 18$ reference genes,

261 which were previously characterized and determined as optimal endogenous controls ${ }^{30}$. Measurements

262 were taken from three biological replicates, all of which included three technical replicates per reaction

263 and a no-template negative control.

264 Malpighian tubule fluid secretion assay. In order to determine fluid secretion rates, a modified Ramsay

265 secretion assay ${ }^{65}$ was performed on isolated MTs of 3-6 day old adult female A. aegypti, as reported

266 recently ${ }^{37}$. Tissue dissections were performed under physiological saline prepared as described

267 previously $^{66}$ diluted 1:1 with Schneider's Insect Medium (Sigma-Aldrich, Oakville, ON). Individual MTs

268 were removed and transferred to a Sylgard-lined Petri dish containing $20 \mu$ saline bathing droplets

269 immersed in hydrated mineral oil to prevent evaporation. The proximal end of the MT was removed from

270 the bathing saline and wrapped around a Minuten pin to allow for secretion measurements. Dosages of 25

$271 \mathrm{nmol} \mathrm{l}^{-1}$ Drome $\mathrm{DH}_{31}{ }^{22}$ or $100 \mathrm{nmol}^{-1} 5-\mathrm{HT}^{67,68}$ alone or in combination with $1 \mathrm{fmol}^{-1}$ AedaeCAPA-1 37

272 were applied to the isolated MTs as previously described ${ }^{37}$. To investigate the effects of the 
273 pharmacological blockers, a nitric oxide synthase (NOS) inhibitor, $\mathrm{N}_{\omega}$-Nitro-L-arginine methyl ester

274 hydrochloride (L-NAME), and protein kinase G (PKG) inhibitor, KT5823, were used against 5-HT- and

$275 \mathrm{DH}_{31}$-stimulated MTs. Dosages of $2 \mu \mathrm{mol} 1^{-1}$ L-NAME (manufacturer's recommended dose) and $5 \mu \mathrm{mol}$

$2761^{-1}$ KT5823 36 were applied to the MTs. The inhibitors were treated in conjunction with $1 \mathrm{fmol} 1^{-1}$

277 AedaeCAPA-1 and/or $100 \mathrm{nmol}^{-1}$ cyclic guanosine monophosphate, 8 bromo-cGMP $(\mathrm{cGMP})^{37}\left(\right.$ Sigma- $^{-}$

278 Aldrich, Oakville, ON, Canada). Unstimulated controls consisted of tubules bathed in physiological saline

279 with no diuretic application. Following a 60-minute incubation period, the size of the secreted droplet was

280 measured using an eyepiece micrometer and fluid secretion rate (FSR) was calculated as described

281 previously ${ }^{21}$. 


\section{$\underline{\text { Results }}$}

Anti-diuretic hormone receptor identification and sequence analysis. The complete CAPA receptor in

A. aegypti was identified and found to be $3461 \mathrm{bp}$ with an open reading frame of $2139 \mathrm{bp}$ encoding a receptor protein of 712 residues. The 5' and 3' untranslated regions were comprised of 899bp and 423bp, respectively (Figure S1A). The gene structure model revealed the cloned cDNA mapped to eleven exons spanning a genomic region of over $351 \mathrm{~Kb}$, with the start codon positioned within the third exon and the translation termination (stop) codon located in the eleventh exon, which is also contains the predicted

291 polyadenylation signal at nucleotide position 3405-3410 (Figure S1B). The deduced protein sequence 292 encodes a receptor protein that displays the prototypical features of rhodopsin receptor-like (family A)

293 GPCRs ${ }^{69-71}$, including the highly conserved tryptophan residue in the first extracellular loop involved in 294 receptor trafficking, the D/E-R-Y/F motif at the border between the third transmembrane domain and 295 second intracellular loop along with the NSxxNPxxY motif found within the seventh transmembrane 296 domain (Figure S1A). Phylogenetic analysis using maximum likelihood methods revealed the deduced 297 receptor protein sequence shares greatest evolutionary relationship with the orthologous CAPA receptor 298 proteins identified or predicted in other dipterans organisms, including for example the fruit fly, non-

299 biting midges, house fly, blow fly along with the more closely-related sister mosquito species (Figure S2). cloned anti-diuretic hormone receptor were identified using a heterologous functional assay using CHO-

302 K1 cells stably expressing a bioluminescent calcium sensor, aequorin ${ }^{58,61}$. The receptor was activated by

303 all endogenously expressed peptides encoded by the CAPA gene in A. aegypti (Figure 1A), including two

304 CAPA peptides (periviscerokinins) and a pyrokinin 1-related peptide. Notably however, the pyrokinin 1305 related peptide displayed very poor activity compared to the two CAPA peptides, which were the most 306 potent ligands with half maximal effective concentrations in the low nanomolar range $\left(\mathrm{EC}_{50}=5.62-6.76\right.$ $307 \mathrm{nM}$ ), whereas a significantly higher concentration of pyrokinin-1 was needed to achieve even low level 308 CAPAr activation. Several other endogenous mosquito peptides as well as additional insect peptides 
belonging to distinct peptide families were tested and displayed no detectable activity over background levels of luminescence (Figure 1B). Controls where the CHO-K1-aeq cells were transfected with empty pcDNA3. $1^{+}$vector showed no detectable luminescence response (data not shown) to any of the peptides used in this study, confirming the calcium-based luminescence signal was a result of CAPA neuropeptide ligands activating the transiently expressed $A$. aegypti CAPA receptor.

$314 \boldsymbol{C A P A r}$ transcript profile and cell-specific localization. We determined the developmental expression

315 profile of the A. aegypti CAPA receptor (CAPAr) transcript in each post-embryonic developmental stage

316 of the mosquito. Over the four larval stages and pupal stage of development, the CAPAr transcript level

317 remained unchanged (Figure 2A); however, in adults, CAPAr transcript levels were significantly higher in

318 adult male mosquitoes compared to adult female, pupal stage and first instar larval mosquitoes (Figure

319 2A). To confirm sites of biological action of the anti-diuretic hormones in vivo, we determined the CAPAr

320 expression profile in adult $A$. aegypti, examining several tissues/organs in adult male and female

321 mosquitoes. In males, CAPAr transcript was detected in reproductive tissues, head, carcass (i.e. the

322 headless mosquito excluding the alimentary canal and reproductive tissues), midgut and low levels in the

323 hindgut (Figure 2B). Enrichment of the CAPAr transcript was observed in the Malpighian 'renal' tubules

324 (MTs) where expression was significantly enriched by 150-fold compared to all other tissues/organs

325 examined (Figure 2B). A similar expression profile was observed in female mosquitoes with CAPAr

326 transcript present in head, carcass, midgut and low levels detected in hindgut and reproductive organs.

327 Similar to males, CAPAr was significantly enriched in the MTs of females relative to all other examined

328 tissues/organs by nearly 150-fold (Figure 2B). Using fluorescent in situ hybridization, the CAPAr

329 transcript was localized specifically to principal cells of the MTs and absent in stellate cells (Figure 2C).

330 Specificity of CAPAr transcript localization was confirmed using sense control probe, with no signal

331 detected in any cell type of the MTs (Figure 2D).

\section{CAPA transcript and mature neuropeptide immunolocalization within the abdominal ganglia.}

333 CAPA-like immunoreactivity was localized within all six of the abdominal ganglia, including the 
334 terminal ganglion. Specifically, each abdominal ganglion contains a pair of ventrally-localized strongly

335 immunoreactive neurosecretory cells (Figure 3A). Axonal projections from these CAPA-like

336 immunoreactive neurosecretory cells emanate dorsally and anteriorly within each ganglion, exiting via the

337 median nerve (Figure 3B-C), with immunoreactive projections innervating the perivisceral organs (Figure

338 3D), which are the primary neurohaemal release sites in the ventral nerve cord facilitating neurohormone

339 delivery into the insect haemolymph ${ }^{72,73}$. Validation that these immunoreactive neurosecretory cells in the

340 abdominal ganglia were indeed CAPA-producing neurons was established by co-localization of CAPA

341 transcript with CAPA-like immunoreactivity. Weakly staining CAPA-like immunoreactive cells were

342 also observed in other regions of the central nervous system, including the brain, suboesophageal

343 ganglion and thoracic ganglia (Figure S3); however, CAPA transcript was significantly enriched ( 140-

344 fold) only within the abdominal ganglia but not in other regions of the nervous system (Figure S4).

345 Within the abdominal ganglia, CAPA transcript co-localized within each pair of strongly staining CAPA-

346 like immunoreactive neurosecretory cells (Figure 3F-H). Preparations treated with CAPA transcript sense

347 probes did not detect any cells in the abdominal ganglia nor anywhere else in the central nervous system.

348 CAPAr knockdown abolishes anti-diuretic hormone activity. To confirm that the anti-diuretic

349 hormone action of the CAPA neuropeptides ${ }^{36,37}$ are mediated through this specific receptor expressed

350 within the principal cells of the MTs, one day-old female A. aegypti were injected with dsCAPAR to

351 knockdown CAPAr transcript levels. Relative to control mosquitoes injected with dsARG (gene cloned

352 from standard plasmid vector encoding the ampicillin-resistance gene), CAPAr transcript was

353 significantly reduced by $\sim 75 \%$ in four-day old females (Figure $4 \mathrm{~A}$ ). With significant knockdown verified

354 in four-day old adult mosquito samples from the same experimental cohort, standard Ramsay assay was

355 conducted as previously described ${ }^{37}$ on dsRNA-treated females to examine whether the anti-diuretic

356 hormone activity of a CAPA anti-diuretic hormone was compromised. Our results confirmed that the

357 CAPA neuropeptide, specifically AedaeCAPA-1, had no inhibitory activity against $\mathrm{DH}_{31}$-stimulated MTs

358 in CAPAr knockdown females (Figure 4B). In contrast, AedaeCAPA-1 potently inhibited $\mathrm{DH}_{31^{-}}$ 
stimulated fluid secretion by MTs in dsARG-treated control female mosquitoes (Figure 4B).

Effect of pharmacological blockade on the inhibition of fluid secretion. To further understand the anti-diuretic signalling pathway involving the CAPA neuroendocrine system, pharmacological blockers, including inhibitors of NOS (L-NAME) and PKG (KT5823), were tested against diuretic hormonestimulated MTs alone and together with either AedaeCAPA-1 or cGMP. In $\mathrm{DH}_{31}$-stimulated MTs, $\mathrm{L}^{-}$

364 NAME had no influence on the inhibitory effect of cGMP whereas the inhibitory effect of AedaeCAPA-1 was abolished (Figure 5A). In 5-HT-stimulated MTs, the results indicate that neither AedaeCAPA-1 nor cGMP inhibition are influenced by L-NAME (Figure 5B). Application of KT5823 abolished the inhibitory effect of both cGMP and AedaeCAPA-1 in $\mathrm{DH}_{31}$-stimulated MTs (Figure 6A). Similarly, the inhibitory activity of AedaeCAPA-1 and cGMP on 5-HT-stimulated tubules was abolished when treated with KT5823 (Figure 6B). Collectively, these results indicate that AedaeCAPA-1 inhibits select diuretic factors acting on the principal cells and involves $\mathrm{NO}$ and cGMP as a second messenger in $\mathrm{DH}_{31}$-stimulatd

371 tubules, whereas cGMP, but not NO, is critical in the anti-diuretic activity of AedaeCAPA-1 on 5HT-

372 stimulated MTs.

\section{Discussion}

Like many animals, insects must regulate the ionic and osmotic levels of their internal

376 environment to ensure homeostatic levels of water and electrolytes are maintained. This is critical not

377 only for challenges linked to feeding, including the intake of too much or too little water and/or ions, but

378 is also important for daily exchange of these elements with the environment through other routes such as

379 waste elimination or water loss during respiration. The insect excretory system acts to maintain

380 hydromineral balance of the haemolymph by either increasing the removal of water and/or ions in excess

381 or the recycling of these same elements when in short supply. The insect Malpighian 'renal' tubules

382 (MTs) play a key role as the organ responsible for primary urine production, which can then be modified

383 by downstream elements of the excretory system such as the hindgut ${ }^{4}$. The MTs are the chief iono- and 
osmoregulatory organ and are under rigorous control by neuroendocrine factors, including both diuretic hormones $(\mathrm{DH})$ and anti-diuretic hormones $(\mathrm{ADH})$, which regulate transepithelial movement of ions and osmotically obliged water. These hormones consist of a variety of peptides as well as other neurochemicals produced by neurosecretory cells in the brain and ventral nerve cord ${ }^{74,75}$. Classically, DHs stimulate primary urine secretion by the MTs, whereas ADHs increase fluid reabsorption from the hindgut ${ }^{15,76}$. However, countless studies in diverse insect species have established that ADHs can also act on the MTs to reduce primary urine secretion ${ }^{31,36-38,40,77}$. CAPA neuropeptides have been demonstrated to display potent anti-diuretic effects in a variety of insects ${ }^{38,39,42,78}$, including A. aegypti mosquitoes ${ }^{36,37}$, while they have been shown to function as DHs and ADHs in D. melanogaster ${ }^{40,79-81}$. hormone system in the disease vector mosquito, A. aegypti, by characterization and functional deorphanization of an anti-diuretic hormone receptor that is highly enriched in the MTs and demonstrates high selectivity for the mosquito CAPA neuropeptides. Previous studies have functionally deorphanized a number of CAPA receptor orthologs in other insects including dipterans ${ }^{44,57,82,83}$, lepidopterans ${ }^{84}$, coleopterans $^{85}$, hemipterans ${ }^{86}$, as well as in the southern cattle tick ${ }^{87}$. Here, we have functionally validated the specific ligands of the elusive A. aegypti CAPA receptor demonstrating that two of the peptides

401 leading to calcium signalling that elicits a bioluminescent response. While none of the other tested ligands 402 representing multiple insect peptide families were active on the mosquito CAPA receptor, the third 403 peptide encoded by the CAPA gene, Aedae-PK1, had low agonist activity with a potency of over five 404 orders of magnitude lower compared to the canonical CAPA ligands. Aedae-PK1 is a member of the 405 pyrokinin-1 family of peptides that contain the GXWFGPRL- $\mathrm{NH}_{2}$ (where normally $\mathrm{X}=\mathrm{V}, \mathrm{M}$ or $\mathrm{L}$ ) 406 consensus C-terminal sequence and recently a revised tryptopyrokinin nomenclature has been adopted to 407 differentiate these neuropeptides from distinct pyrokinin families ${ }^{88}$. In agreement with our findings, a 408 subset of previous studies on insect CAPA receptor orthologs have shown minor responsiveness to 
tryptopyrokinin ligands, with high doses eliciting low level CAPA receptor activation ${ }^{84-86}$. Interestingly,

410 this minor promiscuousness has not been observed for other dipteran CAPA receptors characterized

411 previously $^{57,82,83}$.

413 due to their myotropic activity on visceral muscle and their source of release from the segmental

414 abdominal neurohaemal organs known as perivisceral/perisympathetic organs ${ }^{31,51,85}$. Herein, we have

415 immunolocalized CAPA neuropeptides within a pair of ventral neurosecretory cells within each of the six

416 abdominal ganglia, whose axonal projections extend dorsally and anteriorly exiting each abdominal

417 ganglion via the median nerve. CAPA immunoreactivity extends towards and is localized to the

418 abdominal neurohaemal organs, the perivisceral organs, where these neuropeptides can be released into

419 the haemolymph to elicit their neurohormonal actions on target sites expressing the CAPA receptor. The

420 CAPA transcript was highly enriched within the abdominal ganglia of adult mosquitoes, confirming the

421 transcript encoding the anti-diuretic hormone prepropeptide colocalized to these same neurosecretory

422 cells. In support of these findings, peptidomic approaches using MALDI-TOF mass spectrometry have

423 previously provided evidence for the presence of putative CAPA neuropeptides within isolated abdominal

424 ganglia, including the terminal ganglion, from adult A. aegypti ${ }^{50}$. Collectively, these findings establish

425 that the transcript and the mature peptide are present within the adult mosquito abdominal ganglia with

426 the neurohormones being released into the insect circulatory system to act upon target tissues. Lastly,

427 considering the low level CAPA transcript and immunoreactivity detected in other regions of the nervous

428 system indicates that the abdominal ganglia, and their associated neurohaemal organs, are the primary

429 source of the anti-diuretic hormone in adult A. aegypti. This also corroborates earlier peptidomic studies

430 indicating the absence CAPA peptides, or differential processing of the CAPA precursor, in other regions

431 of the nervous system aside from the abdominal ganglia where these neuropeptides are highly

432 abundant ${ }^{50,89,90}$.

433 Having established the origin of the CAPA neuropeptide anti-diuretic hormones and their potent 
434 activity on the heterologously expressed CAPA receptor (CAPA-R), we next aimed to confirm the

435 expression profile of the transcript encoding CAPA-R. Expression of CAPAr was observed in all post-

436 embryonic ontogenic stages with significant enrichment in adult male mosquitoes, compared to females.

437 Although the biological relevance of this differential expression remains unclear, this may relate to the

438 sexual size dimorphism between adult male and female A. aegypti ${ }^{91}$, with the smaller males being

439 inherently more susceptible to desiccation stress due to their higher surface area to volume ratio. In other

440 insects, $C A P A r$ transcript expression has been observed throughout most post-embryonic developmental

441 stages ${ }^{82,85,92}$. The MTs are composed of two cell types forming a simple epithelium; large principal cells

442 and thin stellate cells ${ }^{74}$. Principal cells facilitate the active transport of cations $\left(\mathrm{Na}^{+}\right.$and $\left.\mathrm{K}^{+}\right)$into the

443 lumen of the MTs from the haemolymph, while the stellate cells facilitate the transepithelial secretion of

$444 \mathrm{Cl}^{-}$, the predominant inorganic anion ${ }^{93}$. In adult stages, expression analysis of $C A P A r$ verified significant

445 enrichment of this receptor in the MTs in both male and female mosquitoes. Furthermore, cell-specific

446 expression mapping confirmed that the CAPAr transcript is restricted to the principal cells of the MTs and

447 absent in the smaller stellate cells. In other insects, CAPAr transcript has been detected in various regions

448 of the alimentary canal ${ }^{85,86,94}$, including the principal cells of the MTs where this receptor is exclusively

449 expressed in the fruit fly ${ }^{44}$. All in all, these observations are in line with physiological roles established for

450 CAPA neuropeptides, which have been shown to modulate rates of fluid secretion by MTs in various

451 insects ${ }^{36-37,41,62,96-97}$. In dipterans, these effects are mediated via action on the principal cells acting

452 through a second messenger cascade involving calcium, nitric oxide and cGMP signalling ${ }^{98,99}$.

453 We next examined whether normal anti-diuretic hormone signalling, which requires the

454 neuronally-derived CAPA peptide hormones activating their receptor expressed in the principal cells of

455 the MTs, could be impeded by using RNA interference against the CAPAr transcript. One-day old

456 mosquitoes were injected with CAPAr-targeted dsRNA resulting in knockdown at four-day old, where

$457 C A P A r$ transcript was significantly reduced. We examined whether CAPAr knockdown females retained

458 sensitivity to CAPA peptides, which have been shown to inhibit fluid secretion by MTs by select diuretic 
hormones $^{37}$. Indeed, CAPAr knockdown abolished the anti-diuretic activity of a CAPA neuropeptide to the CAPA peptide family, are produced in pairs of neurosecretory cells in each of the abdominal

463 ganglia whereby they are released through the neurohaemal organs and influence the MTs by acting on

464 their receptor expressed within the principal cells of this organ. Further, the results confirm that sustained 465 anti-diuretic hormone signalling, which requires the steady state expression of ligand and receptor, is 466 necessary for facilitating the anti-diuretic control of the MTs.

In D. melanogaster and other dipterans, CAPA peptides have been shown to stimulate the nitric oxide (NO)/cGMP signalling pathway to induce diuresis ${ }^{98}$. When released, CAPA peptides bind to

469 GPCRs found in principal (type I) cells of MTs, increasing $\mathrm{Ca}^{2+}$ levels in the cell through activation of L470 type voltage gated calcium channels ${ }^{100}$. The influx of $\mathrm{Ca}^{2+}$ through these channels activates NOS, causing 471 the production of NO, which subsequently activates guanylate cyclase to increase levels of cGMP in the $472 \mathrm{MTs}^{44}$. Ultimately, the activation of the NO/cGMP pathway stimulates the apical V-type $\mathrm{H}^{+}$-ATPase 473 (proton pump), to increase fluid secretion in D. melanogaster. In the mosquito A. aegypti, CAPA peptides

474 lead to activation of PKG, via elevated levels of $\mathrm{cGMP}^{36}$ and exogenous cGMP considerably inhibits fluid 475 secretion rate ${ }^{37}$. Here, we sought to establish the roles of NO, cGMP and PKG on the anti-diuretic effects 476 of CAPA peptides on adult mosquito MTs. Inhibitory doses of cGMP and a CAPA neuropeptide, namely

477 AedaeCAPA-1, were treated with a NOS inhibitor, L-NAME, and a PKG inhibitor, KT5823. These

478 investigations established that ${ }_{\text {L }}$ NAME did not alter the inhibitory effects of exogenous cGMP since this 479 drug inhibits NOS, which is upstream of cGMP and, as a result, inhibition of $\mathrm{DH}_{31}$-stimulated secretion 480 was unaffected. Contrastingly, AedaeCAPA-1 mediated inhibition of $\mathrm{DH}_{31}$-stimulated MTs was mitigated 481 in the presence of ${ }_{\mathrm{L}}$-NAME, reducing the anti-diuretic effects observed with AedaeCAPA-1.

482 Comparatively, these findings are similar but are not identical to the effects of the PKG inhibitor, 483 KT5823, which abolished the anti-diuretic activity of both AedaeCAPA-1 and cGMP, resulting in normal 
$484 \mathrm{DH}_{31}$-induced diuresis. Similar results were observed in 5-HT-stimulted MTs with one exception;

485 AedaeCAPA-1 inhibition appeared to be independent of NOS since ${ }_{\text {L }}$ NAME had no influence on the

486 anti-diuretic activity of AedaeCAPA-1 in 5-HT-stimulated MTs. Interestingly, the inhibition of both

$487 \mathrm{DH}_{31}$ - and 5-HT stimulated diuresis by AedaeCAPA-1 and cGMP were sensitive to the PKG inhibitor,

488 KT5823, which indicates that while some differences in signalling associated with inhibition of different

489 diuretic hormones may occur, these inhibitory pathways likely converge and involve cGMP activating

490 protein kinase G. Taken together, the findings in this study provide definitive evidence that CAPA

491 peptides are anti-diuretic hormones in the mosquito A. aegypti, which inhibit fluid secretion of adult

492 mosquito MTs through a signalling cascade involving the NOS/cGMP/PKG pathway. Further studies are

493 necessary in mosquitoes as well as other insects to elucidate the differential regulation by DHs and ADHs

494 given ample data supporting that cGMP and related effectors can be both stimulatory ${ }^{44,79,99,101}$ and

495 inhibitory ${ }^{31,32,36-37,43,81,102}$ in their control on insect MTs. In conclusion, we have established an anti-

496 diuretic hormone system in the adult mosquito A. aegypti providing evidence of a neural-renal axis

497 whereby the neuropeptidergic anti-diuretic hormone is released by the abdominal segmental neurohaemal

498 organs and subsequently targets their cognate receptor expressed within the principal cells of the MTs to

499 counteract the activity of a subset of mosquito diuretic hormones. Fine-tuning of stimulatory and

500 inhibitory hormones controlling the insect excretory system is of utmost importance to ensure overall

501 organismal homeostasis to combat variable environmental conditions or feeding-related states that could

502 perturb hydromineral balance if left unregulated. 


\section{Figure captions}

506

507

508

509

510

511

512

513

514

515

516

517

518

519

520

521

522

523

524

525

526

527

528

529

530

531

532

533

534

535

536

537

538

539

540

541

542

543

Figure 1. CAPA neuropeptide (anti-diuretic hormone) receptor (CAPAr) functional deorphanization using a heterologous assay. (A) Normalized dose-response curve demonstrating specificity of CAPAr functional activation by CAPA gene-derived neuropeptides. (B) Raw luminescent response following application of each CAPA gene-derived neuropeptide and representative neuropeptides belonging to several insect families, each tested at $10 \mu \mathrm{M}$. For peptide sequence information and species origin, see Table S3. Only CAPA gene-derived neuropeptides resulted in a significant luminescent response relative to BSA control (vehicle). At this saturating dose, no difference in response was observed between the two endogenous CAPA neuropeptides, AedaeCAPA1 and AedaeCAPA2; AedaePK1, demonstrated a significantly lower luminescent response (only 20\% activity compared to either CAPA peptide), but nonetheless this response was significantly higher compared to all other tested peptides that were identical to background luminescent responses obtained with vehicle control (BSA). Different letters denote bars that are significantly different from one another as determined by one-way ANOVA and Tukey's multiple comparison post-hoc test ( $\mathrm{p}<0.01$ ). Data represent the mean \pm standard error ( $\square=\square 3$ ).

Figure 2. Expression analysis of CAPAr transcript in the mosquito, A. aegypti. (A) Ontogenic expression profile of $C A P A r$ transcript over post-embryonic stages of the A. aegypti mosquito shown relative to transcript levels in $1^{\text {st }}$ instar larvae. (B) Spatial expression is analyzed in various tissues/organs from fourday old adult females, with transcript abundance shown relative to levels in the male midgut. (C) Cellspecific expression of CAPAr mRNA in principal cells (arrows) of MTs from adult female A. aegypti detected using an anti-sense probe, with no detection in the stellate cells (arrowheads). (D) No signal was detected in preparations hybridized with control CAPAr sense probe. All images acquired using identical microscope settings; scale bars in C-D are $100 \mu \mathrm{m}$.

Figure 3. Mapping of anti-diuretic hormone in the abdominal ganglia of the central nervous system and associated neurohaemal organs in adult A. aegypti. (A) Immunohistochemical distribution of CAPA neuropeptides in the abdominal ganglia (AG); specifically, a pair of highly immunoreactive neurosecretory cells within AG1-2 (A), AG3-4 (A') and AG4-6 (A'). Higher magnification of AG3 (B) and AG4 (C) demonstrating CAPA immunoreactivity within large ventrally-positioned neurosecretory cells with axonal projections emanating dorsally within the ganglia and projecting anteriorly into the median nerve. (D) CAPA immunoreactivity in abdominal preparations with dorsal cuticle removed leaving the ventrally-localized AG within the abdominal segment showing immunoreactive processes innervating the abdominal neurohaemal (perivisceral) organs. CAPA transcript localization by fluorescent in situ hybridization revealing pairs of neurons within each AG including AG1 (E), AG2 (E'), AG3 (E') and AG4-5 and the sixth terminal abdominal ganglion (TAG; E"'). Co-localization of CAPA immunoreactivity (F) and CAPA transcript (G) was verified in all abdominal ganglia with representative preparation in $(\mathrm{H})$ showing transcript and immunoreactivity co-detection and overlap. Scale bars: $200 \mu \mathrm{m}$ (A \& D), $100 \mu \mathrm{m}(\mathrm{B}-\mathrm{C})$ and $50 \mu \mathrm{m}(\mathrm{E}-\mathrm{H})$. 
Figure 4. RNA interference (RNAi) of CAPAr abolishes anti-diuretic activity of CAPA neuropeptide on adult female A. aegypti MTs. (A) Verification of significant knockdown ( $>75 \%$ ) of CAPAr transcript in MTs of four-day old adult female A. aegypti by RNAi achieved through injection of dsCAPAr on day one post-eclosion. (B) Functional consequences of $C A P A r$ knockdown demonstrating loss of anti-diuretic hormone activity by AedaeCAPA-1 against Drome $\mathrm{DH}_{31}$-stimulated fluid secretion by MTs. In (A), knockdown of CAPAr transcript was analyzed by one-tailed t-test (* denotes significant knockdown, $\mathrm{p}<$ 0.01). In (B), fluid secretion rates by MTs presented as mean \pm SEM and analyzed by one-way ANOVA and Tukey's multiple comparison post-test, where different letters denote treatments that are significantly different $(\mathrm{p}<0.05, \mathrm{n}=14-33)$.

Figure 5. Effect of a nitric oxide synthase (NOS) inhibitor (L-NAME) on the anti-diuretic activity of AedaeCAPA-1 and cGMP in Drome $\mathrm{DH}_{31}$-stimulated A. aegypti MTs. The NOS inhibitor, ${ }_{\mathrm{L}}$-NAME, was applied against (A) Drome $\mathrm{DH}_{31}$ - and (B) 5HT-stimulated MTs alone or in the presence of either AedaeCAPA-1 or cGMP. Secretion rates are presented as mean \pm SEM, $\mathrm{n}=17-22$. Columns that are significantly different from unstimulated controls are denoted with a distinct letter, as determined by a one-way ANOVA and Bonferroni post-test $(\mathrm{p}<0.05)$.

562 Figure 6. Effect of a protein kinase G (PKG) inhibitor (KT5823) on the anti-diuretic activity of 563 AedaeCAPA-1 and cGMP in Drome $\mathrm{DH}_{31}$-stimulated A. aegypti MTs. The PKG inhibitor, KT5823, was 564 applied against (A) Drome $\mathrm{DH}_{31}$ - and (B) 5HT-stimulated MTs alone or in the presence of either 565 AedaeCAPA-1 or cGMP. Secretion rates are presented as mean \pm SEM, $n=16-25$. Columns that are significantly different from unstimulated controls are denoted with a distinct letter, as determined by a one-way ANOVA and Bonferroni post-test $(\mathrm{p}<0.05)$.

Supplementary file captions:

Figure S1. Sequence and gene structure of A. aegypti anti-diuretic hormone receptor. (A) The complete cDNA sequence (lowercase) and deduced protein sequence comprised of 712 amino acid residues (uppercase) along with predicted transmembrane domains (denoted by black highlighted residues) and other features as reported in the results text. Predictions of receptor features are described in the methods section. Nucleotides belonging to different exons are indicated by alternative blue/black font colour. Predicted polyadenylation signal is underlined in the 3' untranslated region. (B) Exons with relative size to one another drawn to scale and denotes the open reading frame (in darker gray shading) beginning with the start codon in the third exon and stop codon within the eleventh exon. Intron sizes are predicted based on comparison of the deduced completed cDNA sequence with the A. aegypti genome scaffolds assessed on a local database using Geneious bioinformatics software (see methods for details). Predicted intron sizes range from as small as 415bp (between exons 6-7) and as large as 74,016bp (between exons 1-2) 
with the entire gene spanning a genomic region of $>351 \mathrm{~kb}$.

584 Figure S2. Molecular phylogenetic relationship of insect CAPA receptors inferred using the maximum likelihood method. Shown is the tree with the highest log likelihood with the numbers adjacent to the branches denoting the percentage of trees in which the associated taxa clustered together. A heuristic search was conducted to deduce an initial tree by applying Neighbor-Join and BioNJ algorithms to a matrix of pairwise distances estimated using a JTT model. Following this initial analysis, the topology with superior log likelihood value was selected automatically. Branch lengths are drawn to scale and denote the number of substitutions per site based on the final analysis involving 42 amino acid sequences and a total of 206 residue positions in the final data set with positions containing gaps and missing data removed. The human neuromedin $\mathrm{U}$ receptor 2 was included in the analysis and designated as the

Figure S3. CAPA immunoreactivity observed in regions of the nervous system aside from the stronglystaining pair of neurosecretory cells in each of the abdominal ganglia. (A) CAPA immunoreactive staining in the brain showing a bilateral pair of neurons in each hemisphere of the brain and immunoreactive processes in the central margin with unknown origin. In the posterior suboesophageal ganglion, a number of small bilaterally-paired neurons (20-30 cells total) were detected. (B) In the fused thoracic ganglia, CAPA immunoreactive processes were observed on the ventral surface, with no consistently detected immunorective neurons. Although a qualitative observation, CAPA immunoreactive staining was substantially weaker in the brain, SOG and thoracic ganglia since exposure and gain settings on the fluorescence microscope were adjusted substantially to enable detection of weak immunoreactive

604 staining. Scale bars: $100 \mu \mathrm{m}$.

Figure S4. Expression analysis of CAPA neuropeptide (anti-diuretic hormone) transcript in different regions of the nervous system relative to whole adult (A) male and (B) female A. aegypti mosquitoes. Different letters denote bars that are significantly different from one another as determined by one-way ANOVA and Tukey's multiple comparison post-hoc test $(\mathrm{p}<0.01)$. Data represent the mean \pm standard 
612 Table S1. Oligonucleotides used for initial amplification and subsequent identification of the complete 613 cDNA (including 5' and 3' UTR) encoding the Aedes aegypti anti-diuretic hormone (CAPA) receptor.

\begin{tabular}{|c|c|c|c|}
\hline Oligo name & Oligo sequence ( $\left(5^{\prime} 3^{\prime}\right)$ & Function & $\begin{array}{c}\text { Accession (nucleotide } \\
\text { position) }\end{array}$ \\
\hline AedesCAPAr F0 & GTGACCATTCTCTTCACGG & $\begin{array}{c}\text { amplification of } \\
\text { partial capaR } \\
\text { sequence }\end{array}$ & $\begin{array}{l}\text { MN433886 } \\
(1326-1344)\end{array}$ \\
\hline AedesCAPAr R0 & CAGCTTGGAGCTCTCGCAGC & $\begin{array}{l}\text { amplification of } \\
\text { partial capaR } \\
\text { sequence }\end{array}$ & $\begin{array}{l}\text { MN433886 } \\
(2327-2308)\end{array}$ \\
\hline AedesCAPAr F1 & CGTCGTGGGCAATTTGATT & $\begin{array}{l}\text { 3'RACE } \\
\text { primer\#1 }\end{array}$ & $\begin{array}{l}\text { MN433886 } \\
(1361-1379)\end{array}$ \\
\hline AedesCAPAr F2 & TATCCGATTTGATCCTGCTGC & $\begin{array}{l}\text { 3'RACE } \\
\text { primer\#2 }\end{array}$ & $\begin{array}{l}\text { MN433886 } \\
(1450-1470)\end{array}$ \\
\hline AedesCAPAr F3 & GTTTCTGGCCATCTGTCATCC & $\begin{array}{l}\text { 3'RACE } \\
\text { primer\#3 }\end{array}$ & $\begin{array}{l}\text { MN433886 } \\
(1616-1636)\end{array}$ \\
\hline AedesCAPAr R1 & GAAAACAGCCACGTATTGACC & $\begin{array}{l}\text { 5'RACE } \\
\text { primer\#1 }\end{array}$ & $\begin{array}{l}\text { MN433886 } \\
(2128-2108)\end{array}$ \\
\hline AedesCAPAr R2 & TCCGGATAATCGCCTTTTTCG & $\begin{array}{l}\text { 5'RACE } \\
\text { primer\#2 }\end{array}$ & $\begin{array}{l}\text { MN433886 } \\
(2007-1987)\end{array}$ \\
\hline AedesCAPAr R3 & GATTTGCATTCCCATCCG & $\begin{array}{l}\text { 5'RACE } \\
\text { primer\#3 }\end{array}$ & $\begin{array}{l}\text { MN433886 } \\
(1913-1896)\end{array}$ \\
\hline
\end{tabular}

Table S2. List and primary structure of several insect neuropeptides tested for functional activation of the mosquito anti-diuretic hormone (CAPA) receptor using heterologous bioassay. NA denotes peptides with 618 no detectable activity when tested up to $10 \mu \mathrm{M}$.

\begin{tabular}{|c|c|c|c|}
\hline Peptide Family (Name) & Sequence & EC $_{50}$ on CAPAr & Species (reference) \\
\hline CAPA (CAPA1) & GPTVGLFAFPRV-NH ${ }_{2}$ & $6.76 \mathrm{nM}$ & $\begin{array}{c}\text { Aedes aegypti } \\
\text { (Predel et al., 2010) }\end{array}$ \\
\hline CAPA (CAPA2) & pQGLVPFPRV-NH ${ }_{2}$ & $5.62 \mathrm{nM}$ & Aedes aegypti \\
\hline
\end{tabular}




\begin{tabular}{|c|c|c|c|}
\hline & & & (Predel et al., 2010) \\
\hline Pyrokinin-1 (PK1) & AGNSGANSGMWFGPRL-NH ${ }_{2}$ & $>10 \mu \mathrm{M}$ & $\begin{array}{c}\text { Aedes aegypti } \\
\text { (Predel et al., 2010) }\end{array}$ \\
\hline Pyrokinin-2 (PK2-1) & NTVNFSPRL-NH ${ }_{2}$ & NA & $\begin{array}{l}\text { Rhodnius prolixus (Paluzzi } \\
\text { \& O’Donnell, 2012) }\end{array}$ \\
\hline Pyrokinin-2 (PK2-2) & SPPFAPRL-NH ${ }_{2}$ & NA & $\begin{array}{l}\text { Rhodnius prolixus (Paluzzi } \\
\text { \& O'Donnell, 2012) }\end{array}$ \\
\hline SIFamide peptide (SIFa) & GYRKPPFNGSIF-NH $_{2}$ & NA & $\begin{array}{c}\text { Aedes aegypti } \\
\text { (Predel et al., 2010) }\end{array}$ \\
\hline $\begin{array}{c}\text { Extended FMRFamides } \\
(\text { FMRFa-1) }\end{array}$ & SALDKNFMRF-NH ${ }_{2}$ & NA & $\begin{array}{c}\text { Aedes aegypti } \\
\text { (Predel et al., 2010) }\end{array}$ \\
\hline $\begin{array}{l}\text { Short neuropeptide F } \\
\text { (sNPF) }\end{array}$ & KAVRSPSLRLRF-NH ${ }_{2}$ & NA & $\begin{array}{c}\text { Aedes aegypti } \\
\text { (Predel et al., 2010) }\end{array}$ \\
\hline $\begin{array}{l}\text { Myoinhibitory peptide } \\
\text { (MIP-7) }\end{array}$ & AWNSLHGGW-NH ${ }_{2}$ & NA & $\begin{array}{l}\text { Rhodnius prolixus } \\
\text { (Paluzzi et al., 2015) }\end{array}$ \\
\hline Leucokinin (kinin) & NSVVLGKKQRFHSWG-NH & NA & $\begin{array}{c}\text { Drosophila melanogaster } \\
\text { (Zandawala et al., 2018) }\end{array}$ \\
\hline Corazonin (CRZ) & pQTFQYSRGWTN-NH ${ }_{2}$ & NA & $\begin{array}{c}\text { Aedes aegypti } \\
\text { (Oryan et al., 2018) }\end{array}$ \\
\hline
\end{tabular}

Table S3. Oligonucleotides used for generation of fluorescent in situ hybridization probes, templates for

621 in vitro dsRNA synthesis and gene-specific primers for quantitative PCR of the Aedes aegypti anti-

622 diuretic hormone (CAPA) receptor.

\begin{tabular}{|l|l|c|c|}
\hline \multicolumn{1}{|c|}{ Oligo name } & Oligo sequence (5'3') & Function & $\begin{array}{c}\text { Accession (nucleotide } \\
\text { position) }\end{array}$ \\
\hline AedesCAPAF fish & GACCTGGACAGCGTCAGC & $\begin{array}{c}\text { FISH probe } \\
\text { template }\end{array}$ & $\begin{array}{c}\text { XM_001650839.1 } \square(28- \\
45)\end{array}$ \\
\hline AedesCAPAR fish & CAGTTCCTTTGATCTCGGTG & $\begin{array}{c}\text { FISH probe } \\
\text { template }\end{array}$ & $\begin{array}{c}\text { XM_001650839.1 } \\
(400-381)\end{array}$ \\
\hline AedesCAPA F1-T7 & $\underline{\text { GAATACGACTCACTATAGG }}$ & $\begin{array}{c}\text { FISH sense } \\
\text { probe template }\end{array}$ & $\begin{array}{c}\text { XM_001650839.1 } \square(28- \\
45)\end{array}$ \\
\hline
\end{tabular}


bioRxiv preprint doi: https://doi.org/10.1101/799833; this version posted October 10,2019 . The copyright holder for this preprint (which was not certified by peer review) is the author/funder, who has granted bioRxiv a license to display the preprint in perpetuity. It is made available under aCC-BY-NC-ND 4.0 International license.

\begin{tabular}{|c|c|c|c|}
\hline AedesCAPA R1-T7 & $\begin{array}{l}\text { TAATACGACTCACTATAGG } \\
\text { GCGA... } \\
\text { CAGTTCCTTTGATCTCGGTG }\end{array}$ & $\begin{array}{l}\text { FISH anti-sense } \\
\text { probe template }\end{array}$ & $\begin{array}{c}\text { XM_001650839.1 } \square \\
(400-381)\end{array}$ \\
\hline AedesCAPA-qPCRfor & $\underline{\text { GCTGTTTGCCTTTCCAAG }}$ & $\begin{array}{l}\text { qPCR forward } \\
\text { primer }\end{array}$ & $\begin{array}{c}\text { XM_001650839.1 } \square(78- \\
95)\end{array}$ \\
\hline AedesCAPA-qPCRrev & $\underline{\text { AACCACATGCCGCTGTTG }}$ & $\begin{array}{l}\text { qPCR reverse } \\
\text { primer }\end{array}$ & $\begin{array}{c}\text { XM_001650839.1 } \\
(344-327)\end{array}$ \\
\hline AedesCAPArRNAiF1 & CCCACGGAAATCATGGACT & $\begin{array}{l}\text { FISH probe and } \\
\text { dsRNA template }\end{array}$ & $\begin{array}{c}\text { MN433886 } \\
(275-293)\end{array}$ \\
\hline AedesCAPArRNAiR1 & GCGGATTTGCATTCCCATC & $\begin{array}{l}\text { FISH probe and } \\
\text { dsRNA template }\end{array}$ & $\begin{array}{l}\text { MN433886 } \\
(1017-999)\end{array}$ \\
\hline AedesCAPArRNAiF-T7 & $\begin{array}{l}\frac{\text { TTTAATACGACTCACTATA }}{\text { GGGAGACCCACGGAAATC }} \\
\text { ATGGACT }\end{array}$ & $\begin{array}{l}\text { FISH sense } \\
\text { probe } \\
\text { and dsRNA } \\
\text { template }\end{array}$ & $\begin{array}{l}\text { MN433886 } \\
(275-293)\end{array}$ \\
\hline AedesCAPArRNAiR-T7 & $\frac{\text { TTTAATACGACTCACTATA }}{\frac{\text { GGGAGAGCGGATTTGCATT }}{\text { CCCATC }}}$ & $\begin{array}{c}\text { FISH anti-sense } \\
\text { probe } \\
\text { and dsRNA } \\
\text { template }\end{array}$ & $\begin{array}{l}\text { MN433886 } \\
(1017-999)\end{array}$ \\
\hline AedesCAPAr-qPCRfor & GATGCTTAGCAATCCGGAA & $\begin{array}{l}\text { qPCR forward } \\
\text { primer }\end{array}$ & $\begin{array}{l}\text { MN433886 } \\
(909-927)\end{array}$ \\
\hline AedesCAPAr-qPCRrev & $\begin{array}{l}\text { GACGGAAAACAGCCACGT } \\
\text { A }\end{array}$ & $\begin{array}{l}\text { qPCR reverse } \\
\text { primer }\end{array}$ & $\begin{array}{l}\text { MN433886 } \\
(1239-1221)\end{array}$ \\
\hline
\end{tabular}




\section{$\underline{\text { References }}$}

626 1. Schoofs, L., De Loof, A. \& Van Hiel, M. B. Neuropeptides as regulators of behavior in insects. 627 Annu. Rev. Entomol. 62, 35-52 (2017).

628 2. He, Q., Wu, B., Price, J. \& Zhao, Z. Circadian rhythm neuropeptides in Drosophila: Signals for 629 normal circadian function and circadian neurodegenerative disease. Int. J. Mol. Sci. 18, 886

$630 \quad$ (2017).

631 3. Terhzaz, S. et al. Insect capa neuropeptides impact desiccation and cold tolerance. Proc. Natl.

632 Acad. Sci. U. S. A. 112, 2882-2887 (2015).

633 4. Coast, G. M., Orchard, I., Phillips, J. E. \& Schooley, D. A. Insect diuretic and antidiuretic 634 hormones. Adv. In Insect Phys. 29, 279-409 (2002).

635 5. Hillyer, J. F. Insect heart rhythmicity is modulated by evolutionarily conserved neuropeptides and neurotransmitters. Curr. Opin. Insect Sci. 29, 41-48 (2018).

637 6. Gäde, G. Regulation of intermediary metabolism and water balance of insects by neuropeptides. 638 Annu. Rev. Entomol. 49, 93-113 (2004).

639 7. Nässel, D. R. \& Winther, Å. M. E. Drosophila neuropeptides in regulation of physiology and 640 behavior. Prog. Neurobiol. 92, 42-104 (2010).

641 8. Raikhel, A. S. S., Brown, M. R. R. \& Belles, X. Hormonal control of reproductive processes. in Comp. Mol. Insect Sci. 3, 433-491 (2005).

$6439 . \quad$ Van Wielendaele, P., Badisco, L. \& Vanden Broeck, J. Neuropeptidergic regulation of 644 reproduction in insects. Gen. Comp. Endocrinol. 188, 23-34 (2013).

645 10. Rafaeli, A. Pheromone biosynthesis activating neuropeptide (PBAN): Regulatory role and mode of 646 action. Gen. Comp. Endocrinol. 162, 69-78 (2009). 
647 11. Phillips, J. E. et al. Some major transport mechanisms of insect absorptive epithelia. Comp Biochem Physiol A Comp Physiol 90, 643-650 (1988).

12. Phillips, J., Hanrahan, J., Chamberlin, M. \& Thomson, B. Mechanisms and control of reabsorption in insect hindgut. Adv. In Insect Phys. 19, 330-422 (1986).

651 13. Cantera, R. \& Nässel, D. R. Dual peptidergic innervation of the blowfly hindgut: a light- and electron microscopic study of FMRFamide and proctolin immunoreactive fibers. Comp. Biochem.

14. Steele, R. W., Lange, A. B., Orchard, I. \& Starratt, A. N. Comparison of the myotropic activity of position-2 modified analogues of proctolin on the hindgut of Periplaneta americana and the

15. Coast, G. The endocrine control of salt balance in insects. Gen Comp Endocrinol 152, 332-338 oviduct of Locusta migratoria. J Insect Physiol 43, 931-938 (1997).

16. O’Donnell, M. \& Spring, J. Modes of control of insect Malpighian tubules: synergism, antagonism, cooperation and autonomous regulation. J. Insect Physiol. 46, 107-117 (2000). identification of a diuretic hormone from Zootermopsis nevadensis. Peptides 22, 147-152 (2001).

18. Lehmberg, E. et al. Identification of a diuretic hormone of Locusta migratoria. Biochem Biophys Res Commun 179, 1036-1041 (1991). insects. Proc Natl Acad Sci U S A 97, 6469-6474 (2000). peptidergic diuretic hormone in the blood-feeding bug Rhodnius prolixus: a CRF-related peptide. 
21. Donini, A., O’Donnell, M. J. \& Orchard, I. Differential actions of diuretic factors on the Malpighian tubules of Rhodnius prolixus. J. Exp. Biol. 211, $42-48$ (2008).

22. Coast, G. M., Garside, C., Webster, S. G., Schegg, K. M. \& Schooley, D. A. Mosquito natriuretic peptide identified as a calcitonin-like diuretic hormone in Anopheles gambiae (Giles). J. Exp. Biol. 208, 3281-3291 (2005).

23. Maddrell, S. H., Herman, W. S., Mooney, R. L. \& Overton, J. A. 5-Hydroxytryptamine: a second diuretic hormone in Rhodnius prolixus. J Exp Biol 156, 557-566 (1991).

24. Davies, S.-A. et al. Signaling by Drosophila capa neuropeptides. Gen. Comp. Endocrinol. 188, 60-6 (2013).

25. Cabrero, P. et al. The Dh gene of Drosophila melanogaster encodes a diuretic peptide that acts through cyclic AMP. J. Exp. Biol. 205, 3799-3807 (2002).

26. Audsley, N. \& Phillips, J. E. Stimulants of ileal salt transport in neuroendocrine system of the desert locust. Gen. Comp. Endocrinol. 80, 127-137 (1990).

27. Audsley, N., McIntosh, C. \& Phillips, J. E. Actions of ion-transport peptide from locust corpus cardiacum on several hindgut transport processes. J. Exp. Biol. 173, 275-288 (1992).

28. Audsley, N., Meredith, J. \& Phillips, J. E. Haemolymph levels of Schistocerca gregaria ion transport peptide and ion transport-like peptide. Physiol. Entomol. 31, 154-163 (2006).

29. Audsley, N., Jensen, D. \& Schooley, D. A. Signal transduction for Schistocerca gregaria ion transport peptide is mediated via both cyclic AMP and cyclic GMP. Peptides 41, 74-80 (2013). 
PLoS One 9, e86386 (2014).

692 31. Paluzzi, J.-P. Distribution, activity and evidence for the release of an anti-diuretic peptide in the 693 kissing bug Rhodnius prolixus. J. Exp. Biol. 209, 907-915 (2006).

694 32. Massaro, R. C. et al. The mechanism of action of the antidiuretic peptide Tenmo ADFa in 695 Malpighian tubules of Aedes aegypti. J. Exp. Biol. 207, 2877-2888 (2004).

696 33. Laenen, B., De Decker, N., Steels, P., Van Kerkhove, E. \& Nicolson, S. An antidiuretic factor in 697 the forest ant: purification and physiological effects on the Malpighian tubules. J Insect Physiol $698 \quad 47,185-193(2001)$.

699 34. Lavigne, C., Embleton, J., Audy, P., King, R. R. \& Pelletier, Y. Partial purification of a novel 700 insect antidiuretic factor from the Colorado potato beetle, Leptinotarsa decemlineata (Say) (Coleoptera: Chrysomelidae), which acts on Malpighian tubules. Insect Biochem. Mol. Biol. 31,

35. Eigenheer, R. A., Nicolson, S. W., Schegg, K. M., Hull, J. J. \& Schooley, D. A. Identification of a potent antidiuretic factor acting on beetle Malpighian tubules. Proc Natl Acad Sci U S A 99, 84-89 (2002).

36. Ionescu, A. \& Donini, A. AedesCAPA-PVK-1 displays diuretic and dose dependent antidiuretic potential in the larval mosquito Aedes aegypti (Liverpool). J. Insect Physiol. 58, 1299-1306

708 (2012).

37. Sajadi, F., Curcuruto, C., Al Dhaheri, A. \& Paluzzi, J.-P. Anti-diuretic action of a CAPA neuropeptide against a subset of diuretic hormones in the disease vector, Aedes aegypti. J. Exp. Biol. 221, (2018).

712 38. Quinlan, M. C., Tublitz, N. J. \& O’Donnell, M. J. Anti-diuresis in the blood-feeding insect 
Rhodnius prolixus Stal: the peptide CAP2b and cyclic GMP inhibit Malpighian tubule fluid secretion. J Exp Biol 200, 2363-2367 (1997).

715 39. Coast, G. M., Nachman, R. J. \& Lopez, J. The control of Malpighian tubule secretion in a predacious hemipteran insect, the spined soldier bug Podisus maculiventris (Heteroptera, Pentatomidae). Peptides 32, 493-499 (2011).

40. Rodan, A. R., Baum, M. \& Huang, C.-L. The Drosophila NKCC Ncc69 is required for normal renal tubule function. Am. J. Physiol. Physiol. 303, C883-C894 (2012).

41. Coast, G. M. et al. Neurohormones implicated in the control of Malpighian tubule secretion in plant sucking heteropterans: The stink bugs Acrosternum hilare and Nezara viridula. Peptides 31,

42. Wiehart, U. I. M., Nicolson, S. W., Eigenheer, R. A. \& Schooley, D. A. Antagonistic control of

44. Terhzaz, S. et al. Mechanism and function of Drosophila capa GPCR: a desiccation stress-

732 45. Jurenka, R. The PRXamide Neuropeptide Signalling System. Conserved in Animals. Adv. In $733 \quad$ Insect Phys. 49, 123-170 (2015).

734 46. Gabilondo, H. et al. A targeted genetic screen identifies crucial players in the specification of the 
736 47. Gabilondo, H. et al. Segmentally homologous neurons acquire two different terminal

737 neuropeptidergic fates in the Drosophila nervous system. PLoS One 13, e0194281 (2018).

738 48. Santos, J. G., Pollák, E., Rexer, K.-H., Molnár, L. \& Wegener, C. Morphology and metamorphosis of the peptidergic Va neurons and the median nerve system of the fruit fly, Drosophila

49. Suska, A., Miguel-Aliaga, I. \& Thor, S. Segment-specific generation of Drosophila Capability neuropeptide neurons by multi-faceted Hox cues. Dev. Biol. 353, 72-80 (2011).

743 50. Predel, R. et al. Neuropeptidomics of the mosquito Aedes aegypti. J Proteome Res 9, 2006-2015 $744 \quad$ (2010).

745 51. Predel, R. \& Wegener, C. Biology of the CAPA peptides in insects. Cell. Mol. Life Sci. 63, 2477$2490(2006)$

747 52. Eckert, M., Herbert, Z., Pollak, E., Molnar, L. \& Predel, R. Identical cellular distribution of all 748 abundant neuropeptides in the major abdominal neurohemal system of an insect (Periplaneta 749 americana). J Comp Neurol 452, 264-275 (2002).

750 53. Pollak, E., Eckert, M., Molnar, L. \& Predel, R. Differential sorting and packaging of capa-gene related products in an insect. J Comp Neurol 481, 84-95 (2005).

752 54. Wegener, C., Linde, D. \& Eckert, M. Periviscerokinins in cockroaches: release, localization, and 753 taxon-specific action on the hyperneural muscle. Gen Comp Endocrinol 121, 1-12 (2001).

754 55. Tublitz, N. J. \& Truman, J. W. Identification of neurones containing cardioacceleratory peptides 755 (CAPs) in the ventral nerve cord of the tobacco hawkmoth, Manduca sexta. J Exp Biol 116, 395756410 (1985). 
56. Rocco, D. A., Kim, D. H. \& Paluzzi, J.-P. Immunohistochemical mapping and transcript expression of the GPA2 / GPB5 receptor in tissues of the adult mosquito, Aedes aegypti. Cell Tissue Res. 369, 313-330 (2017).

57. Olsen, S. S., Cazzamali, G., Williamson, M., Grimmelikhuijzen, C. J. P. \& Hauser, F. gambiae. Biochem. Biophys. Res. Commun. 362, 245-51 (2007).

58. Wahedi, A. \& Paluzzi, J.-P. Molecular identification, transcript expression, and functional deorphanization of the adipokinetic hormone/corazonin-related peptide receptor in the disease

59. Gondalia, K., Qudrat, A., Bruno, B., Fleites Medina, J. \& Paluzzi, J. P. Identification and functional characterization of a pyrokinin neuropeptide receptor in the Lyme disease vector,

60. Oryan, A., Wahedi, A. \& Paluzzi, J.-P. V. Functional characterization and quantitative expression analysis of two GnRH-related peptide receptors in the mosquito, Aedes aegypti. Biochem. Biophys. Ixodes scapularis. Peptides 86, 42-54 (2016).

61. Paluzzi, J.-P. et al. Investigation of the potential involvement of eicosanoid metabolites in antiRes. Commun. 497, 550-557 (2018). mapping of a gene encoding an antidiuretic hormone and other CAPA-related peptides in the disease vector, Rhodnius prolixus. Endocrinology 149, 4638-4646 (2008).

63. Paluzzi, J.-P. \& Orchard, I. A second gene encodes the anti-diuretic hormone in the insect, Rhodnius prolixus. Mol Cell Endocrinol 317, 53-63 (2010). 
779

780

781

782

783

784

785

786

787

788

789

790

791

792

793

794

795

796

797

798

799

800

64. Durant, A. C., Chasiotis, H., Misyura, L. \& Donini, A. Aedes aegypti Rhesus glycoproteins contribute to ammonia excretion by larval anal papillae. J. Exp. Biol. 220, 588-596 (2017).

65. Ramsay, J. A. Active transport of water by the Malpighian tubules of the stick insect, Dixippus morosus (Orthoptera, Phasmidae). J. Exp. Biol. 31, 104-113 (1954).

66. Petzel, D. H., Berg, M. M. \& Beyenbach, K. W. Hormone-controlled cAMP-mediated fluid secretion in yellow-fever mosquito. Am. J. Physiol. 253, R701-R711 (1987).

67. Clark, T. M. \& Bradley, T. J. Additive effects of 5-HT and diuretic peptide on Aedes malpighian tubule fluid secretion. Comp. Biochem. Physiol. - A Mol. Integr. Physiol. 119, 599-605 (1998).

68. Veenstra, J. A. Effects of 5-hydroxytryptamine on the Malpighian tubules of Aedes aegypti. J. Insect Physiof 34(4), 299-304 (1988).

69. Schiöth, H. B. \& Fredriksson, R. The GRAFS classification system of G-protein coupled receptors in comparative perspective. Gen. Comp. Endocrinol. 142, 94-101 (2005).

70. Fredriksson, R., Lagerström, M. C., Lundin, L.-G. \& Schiöth, H. B. The G-protein-coupled receptors in the human genome form five main families. Phylogenetic analysis, paralogon groups, and fingerprints. Mol. Pharmacol. 63, 1256-1272 (2003).

71. Rizzo, M. J., Evans, J. P., Burt, M., Saunders, C. J. \& Johnson, E. C. Unexpected role of a conserved domain in the first extracellular loop in G protein-coupled receptor trafficking. Biochem. Biophys. Res. Commun. 503, 1919-1926 (2018).

72. Raabe, M. Synthesis and release sites of neurohormones. in Recent Developments in Insect Neurohormones 1-68 (Springer US, 1989). doi:10.1007/978-1-4613-0805-8_1

73. Raabe, M., Cazal, M., Chalaye, D. \& de Bessé, N. Action cardioaccélératrice des organes neurohémaux périsympathiques ventraux des quelques insectes. Comptes rendus Hebd. des 
seances l'Academie des Sci. Ser. D Sci. Nat. 263, 2002-2005 (1966).

802

803

804

805

806

807

808

809

810

811

812

813

814

815

816

817

818

819

820

821

822

74. Beyenbach, K. W. Transport mechanisms of diuresis in Malpighian tubules of insects. J. Exp. Biol. 206, 3845-3856 (2003).

75. Coast, G. M. Neuroendocrine control of ionic homeostasis in blood-sucking insects. J. Exp. Biol. 212, 378-386 (2009).

76. Phillips, J. Comparative physiology of insect renal function. Am. J. Physiol. 241, R241-57 (1981).

77. Eigenheer, R. A. et al. Isolation, identification and localization of a second beetle antidiuretic peptide. Peptides 24, 27-34 (2003).

78. Paluzzi, J. P. V, Naikkhwah, W. \& O’Donnell, M. J. Natriuresis and diuretic hormone synergism in $R$. prolixus upper Malpighian tubules is inhibited by the anti-diuretic hormone, RhoprCAPA- $\alpha 2$. J. Insect Physiol. 58, 534-542 (2012).

79. Davies, S. A. et al. Neuropeptide stimulation of the nitric oxide signaling pathway in Drosophila melanogaster Malpighian tubules. Am J Physiol 273, R823-7 (1997).

80. Kean, L. et al. Two nitridergic peptides are encoded by the gene capability in Drosophila melanogaster. Am. J. Physiol. Regul. Integr. Comp. Physiol. 282, R1297-307 (2002).

81. MacMillan, H. A. et al. Anti-diuretic activity of a CAPA neuropeptide can compromise Drosophila chill tolerance. J. Exp. Biol. (2018). doi:10.1242/jeb.185884

82. Iversen, A., Cazzamali, G., Williamson, M., Hauser, F. \& Grimmelikhuijzen, C. J. Molecular cloning and functional expression of a Drosophila receptor for the neuropeptides capa-1 and -2. Biochem Biophys Res Commun 299, 628-633 (2002).

83. Park, Y., Kim, Y.-J. \& Adams, M. E. Identification of G protein-coupled receptors for Drosophila PRXamide peptides, CCAP, corazonin, and AKH supports a theory of ligand-receptor 
coevolution. Proc Natl Acad Sci U S A 99, 11423-11428 (2002).

824 84. Shen, Z. et al. BNGR-A25L and -A27 are two functional G protein-coupled receptors for CAPA periviscerokinin neuropeptides in the silkworm Bombyx mori. J. Biol. Chem. 292, 16554-16570 (2017).

85. Jiang, H., Wei, Z., Nachman, R. J., Adams, M. E. \& Park, Y. Functional phylogenetics reveals contributions of pleiotropic peptide action to ligand-receptor coevolution. Sci. Rep. 4, 6800 (2014).

86. Paluzzi, J. P., Park, Y., Nachman, R. J. \& Orchard, I. Isolation, expression analysis, and functional characterization of the first antidiuretic hormone receptor in insects. Proc. Natl. Acad. Sci. U. S. A.

87. Yang, Y., Bajracharya, P., Castillo, P., Nachman, R. J. \& Pietrantonio, P. V. Molecular and functional characterization of the first tick CAP2b (periviscerokinin) receptor from Rhipicephalus

88. Veenstra, J. A. The contribution of the genomes of a termite and a locust to our understanding of (Boophilus) microplus (Acari: Ixodidae). Gen. Comp. Endocrinol. 194, (2013).

89. Predel, R. et al. Peptidomics of CNS-associated neurohemal systems of adult Drosophila melanogaster: a mass spectrometric survey of peptides from individual flies. J Comp Neurol 474,

90. Wegener, C., Reinl, T., Jänsch, L. \& Predel, R. Direct mass spectrometric peptide profiling and fragmentation of larval peptide hormone release sites in Drosophila melanogaster reveals tagmain Aedes mosquitoes (Diptera: Culicidae). Evol. Ecol. Res. 16, 223-234 (2014). 
845 92. Graveley, B. R. et al. The developmental transcriptome of Drosophila melanogaster. Nature 471, 473-479 (2011).

847 93. O’Donnell, M. J., Dow, J. A., Huesmann, G. R., Tublitz, N. J. \& Maddrell, S. H. Separate control of anion and cation transport in Malpighian tubules of Drosophila melanogaster. J. Exp. Biol. 199,

94. Chintapalli, V. R., Wang, J. \& Dow, J. A. Using FlyAtlas to identify better Drosophila melanogaster models of human disease. Nat. Genet. 39, 715-720 (2007).

96. Kean, L. et al. Two nitridergic peptides are encoded by the gene capability in Drosophila melanogaster. Am. J. Physiol. Integr. Comp. Physiol. 282, R1297-R1307 (2002).

97. Halberg, K. A., Terhzaz, S., Cabrero, P., Davies, S. A. \& Dow, J. A. T. Tracing the evolutionary origins of insect renal function. Nat. Commun. 6, 6800 (2015).

98. Pollock, V. P. et al. Conservation of capa peptide-induced nitric oxide signalling in Diptera. J.

99. Davies, S.-A. et al. Signaling by Drosophila capa neuropeptides. Gen. Comp. Endocrinol. 188, 60-66 (2013).

100. MacPherson, M. R. et al. L-type calcium channels regulate epithelial fluid transport in Drosophila melanogaster. Am. J. Physiol. Physiol. 280, C394-C407 (2001). tubule fluid secretion via cGMP. Am J Physiol 269, R1321-6 (1995).

864 102. Ruka, K. A., Miller, A. P. \& Blumenthal, E. M. Inhibition of diuretic stimulation of an insect secretory epithelium by a cGMP-dependent protein kinase. Am J Physiol Ren. Physiol 304, F1210$6(2013)$. 
bioRxiv preprint doi https//doi ora/101101/799833. this version posted October 10 2019. The copvriaht holder for this preprint (which was not certified by peer review) is the author/funder, who has granted bioRxiv a license to display the preprint in perpetuity. It is made available under aCC-BY-NC-ND 4.0 International license. 
A
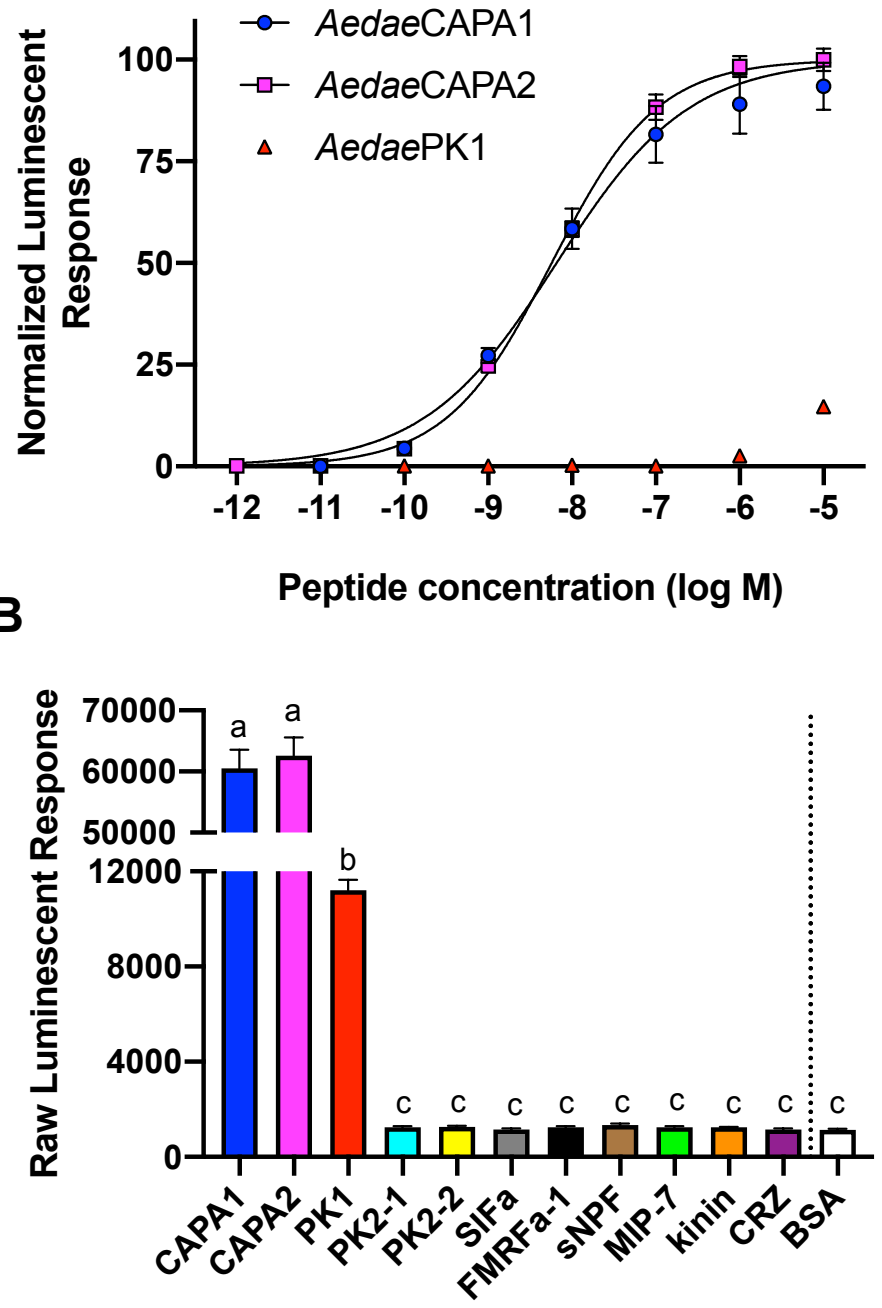

Peptide 
A

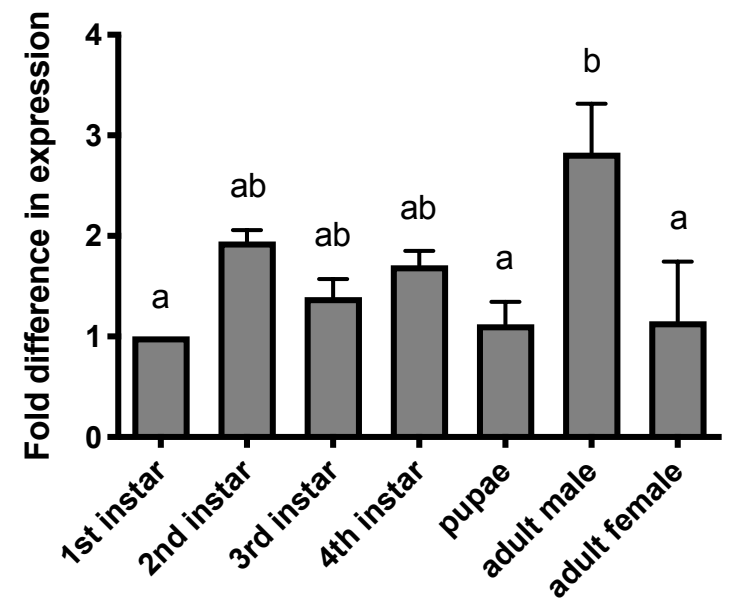

Developmental stage

C

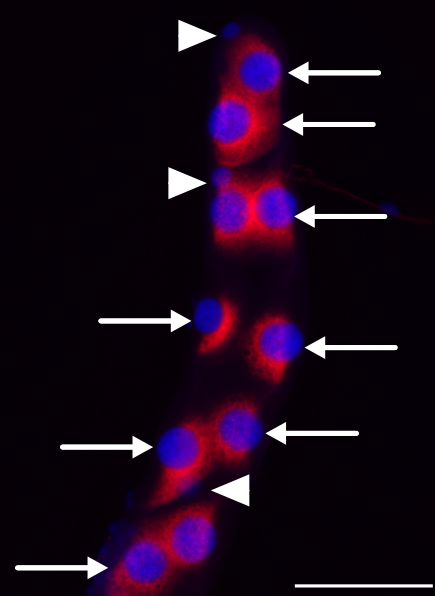

B

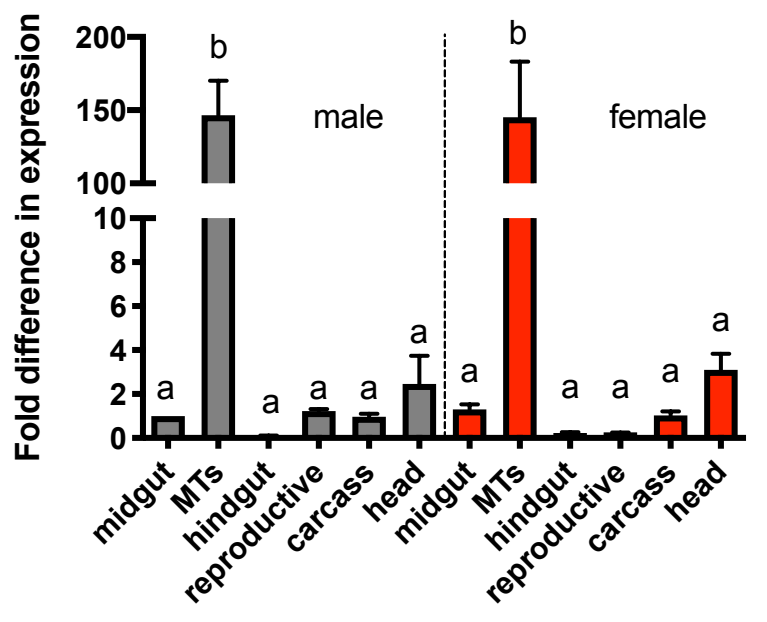

Tissue/Organ 


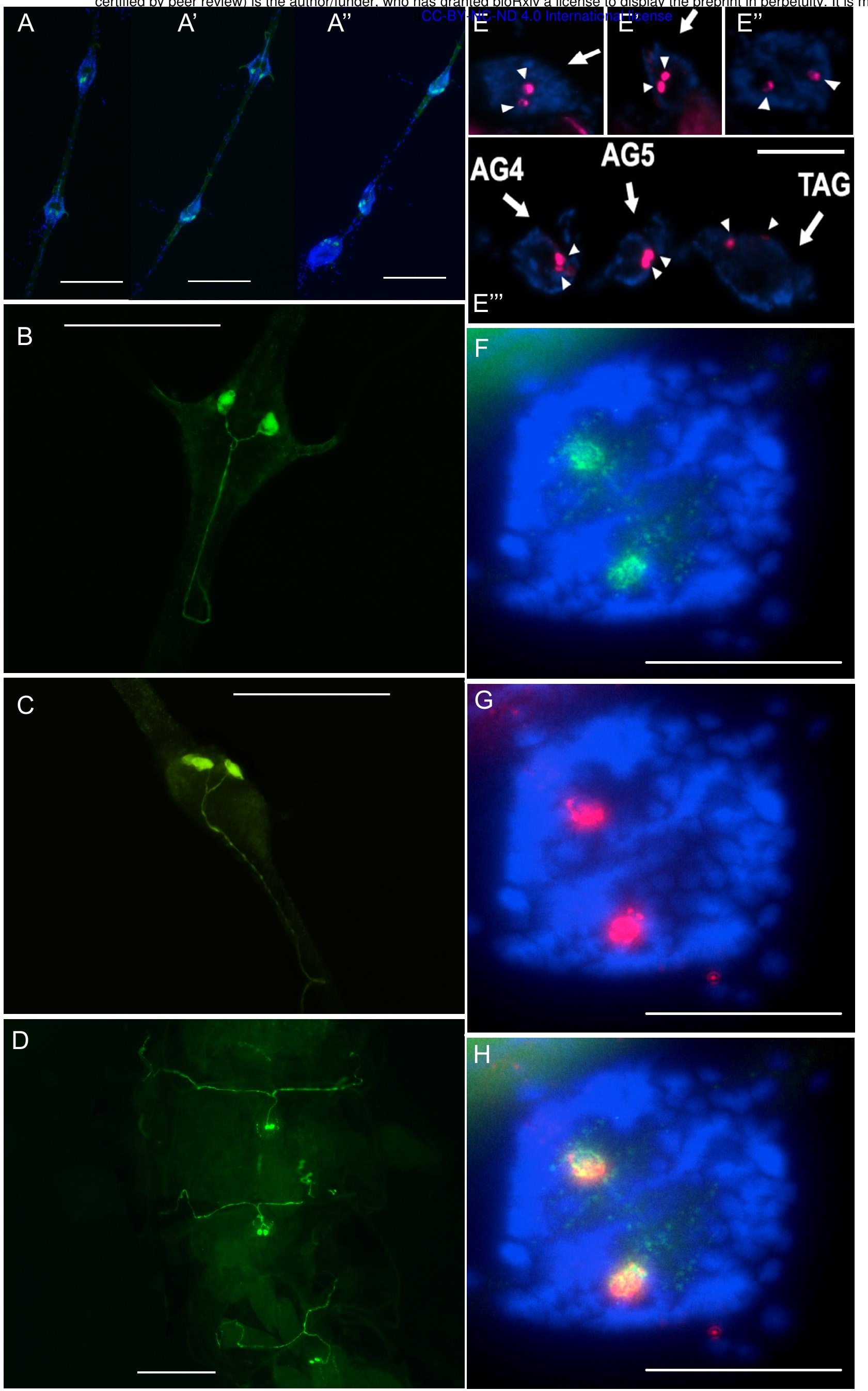




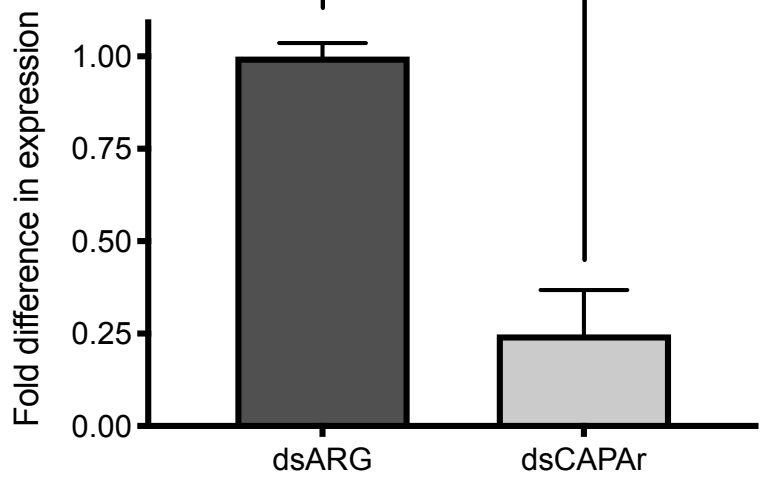

Treatment

B

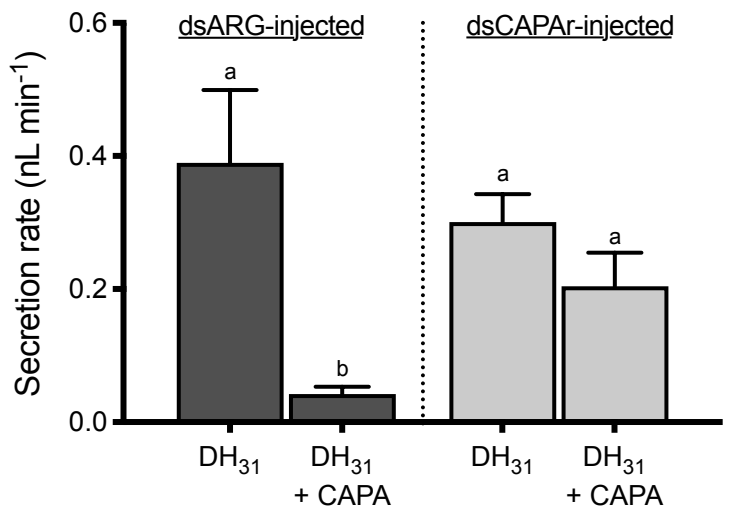

Treatment 
A
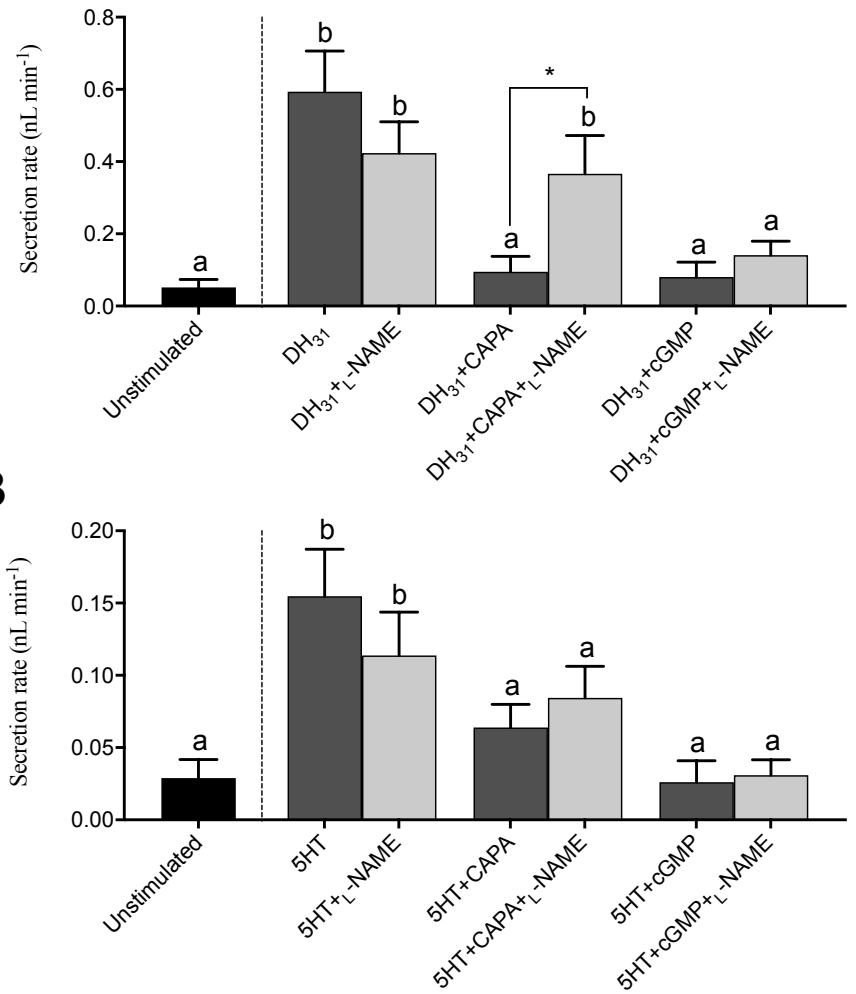


\section{A}
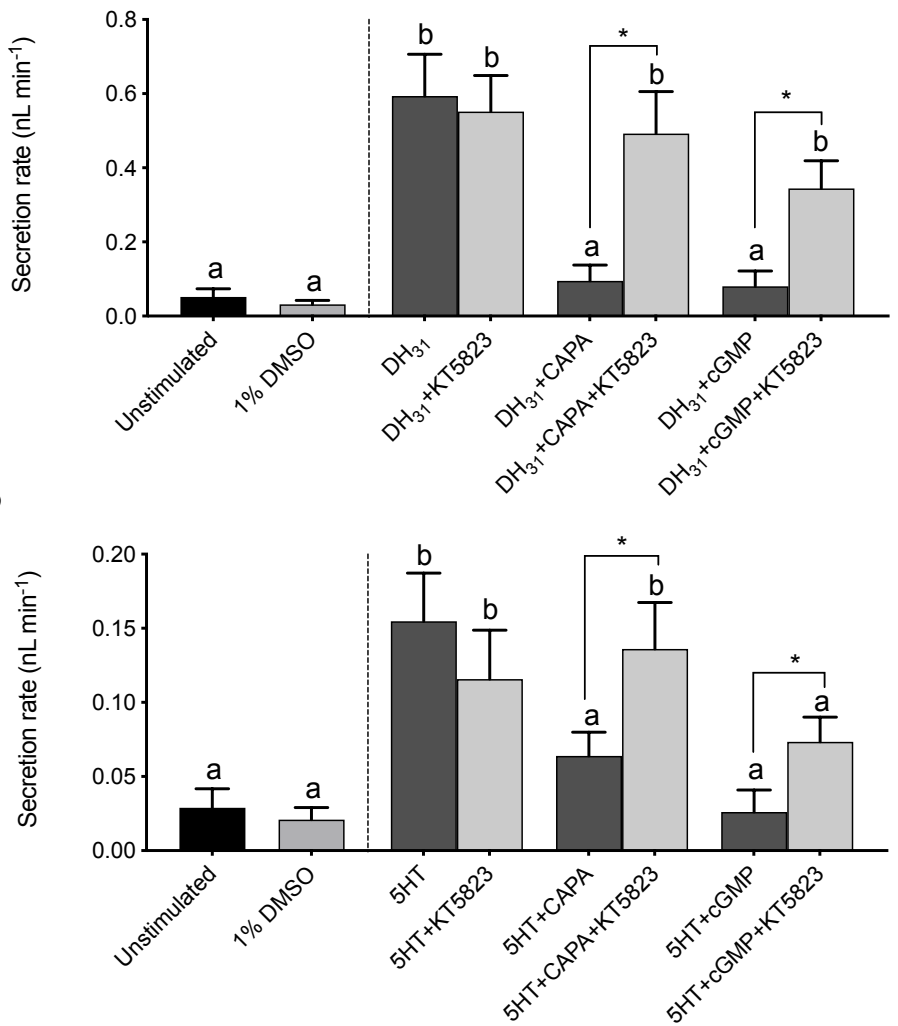
cgaacgcgatttcagctgaagatcacttggagcagattctaatcttggggctctgtcgtgagttttgtgattttggagtgtgcgaagca aggaatcagccagaaaaaggtagtaaatgactgcttttgtgtggaaattgttgcgctagcgtgacaaagatgatttgtgaaaaagctaa atgcatgtgtgacgcggcacggggcgtgatgtgaacatgctgccgtggtcgaccaaattgagctaactgagtgaaaatgtttgattaat tgaggttaaccgcaacggtggattgaagtgacggttatgatgttgcagcatcgtttttatgcggaagatcttggcgcgcaacccgcaaga accgttccttggagcaatctcagtgcagcgaaataaattagaaaatgtgaacacagatttatcgctaatgaaaacagttttcttatc actatttataagaggacgcaagatcgaaaagggtgcaacagggaagaaaaaagtaataagagcgaaattggctccttgttggctgccta gaagaaacggcggtaaagtgcatccccaatgcatttatagaaaaacgtgaagagaagaaagtgcatccaaagtgctggttgggaaca aatcgattacaaaggcggcgatccattcggtcggaagtggaaattgtttcaacgtccgtttatacaccgtttttctcaaaacttatta cggcgaaggagcggaagcaaaaaaagaagtgatgtcggttactgggtgacgaagcacgatggttacttaaaagttggaacactcaattt cgagaacgagtaaaatttgctggcaaattccggctgcctctttgtacctgtaggacggtgtgcgaacggcgtggagtcaccaagtcagg atgactttccacaacttcgacgacgttggcagtggcacgatagaatcgtactggacaaacgccacaaccactgccaggaccacgaccacc $\begin{array}{llllllllllllllllllllllllllllllllllll}M & T & F & H & N & F & D & D & V & G & S & G & T & I & E & S & Y & W & T & N & A & T & T & T & A & R & T & T & T & T\end{array}$ ctcctcacagcacttctgacgacttccctcgggacgtcatcgtcggaacttggtgttgttccatcgaccgccacatccaccttgctggat

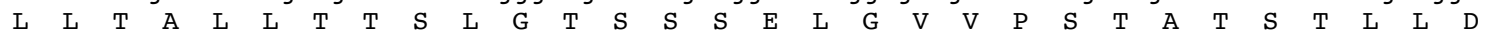
accggttggtggactgactacggaaatggcaccgcgctggagggatacgctggcgttagtgcgaggtggccattcaccggtgaaaactat

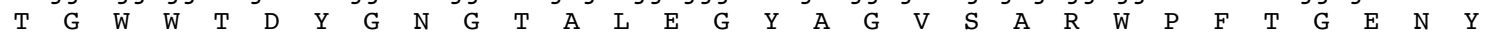
tcgacccacggaaatcatggactcaccggagcggaggaaatcgtaccaccgtacgaccggtgtgatccaagaaacgaaaacttccagtgc $\begin{array}{lllllllllllllllllllllllllllllll}\mathrm{S} & \mathrm{T} & \mathrm{H} & \mathrm{G} & \mathrm{N} & \mathrm{H} & \mathrm{G} & \mathrm{L} & \mathrm{T} & \mathrm{G} & \mathrm{A} & \mathrm{E} & \mathrm{E} & \mathrm{I} & \mathrm{V} & \mathrm{P} & \mathrm{P} & \mathrm{Y} & \mathrm{D} & \mathrm{R} & \mathrm{C} & \mathrm{D} & \mathrm{P} & \mathrm{R} & \mathrm{N} & \mathrm{E} & \mathrm{N} & \mathrm{F} & \mathrm{Q} & \mathrm{C} \\ 1\end{array}$

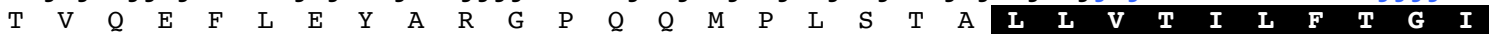
ctcattaccggcgtcgtgggcaatttgattgtgtgtctggtaataattcgacatcctcagatgcacaccgccaccaactactatctgttc $\begin{array}{llllllllllllllllllllllllllllllll}\mathbf{L} & \mathbf{I} & \mathbf{T} & \mathbf{G} & \mathbf{V} & \mathbf{V} & \mathbf{G} & \mathbf{N} & \mathbf{L} & \mathbf{I} & \mathbf{V} & \mathbf{C} & \mathbf{L} & \mathbf{V} & \mathbf{I} & \mathbf{I} & \mathrm{R} & \mathrm{H} & \mathrm{P} & \mathrm{Q} & \mathrm{M} & \mathrm{H} & \mathrm{T} & \mathrm{A} & \mathrm{T} & \mathrm{N} & \mathrm{Y} & \mathbf{Y} & \mathbf{L} & \mathbf{F}\end{array}$

agtttggcc S $\mathbf{I}$.

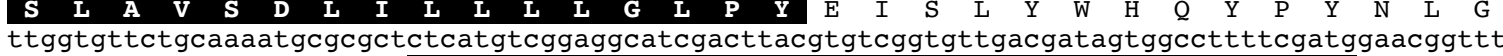
\begin{tabular}{llllllll|llllllllllllllllllllll}
$\mathrm{L}$ & $\mathrm{V}$ & $\mathrm{F}$ & $\mathrm{C}$ & $\mathrm{K}$ & $\mathrm{M}$ & $\mathrm{R}$ & $\mathrm{A}$ & $\mathbf{L}$ & $\mathbf{M}$ & $\mathbf{S}$ & $\mathbf{E}$ & $\mathbf{A}$ & $\mathbf{S}$ & $\mathbf{T}$ & $\mathbf{Y}$ & $\mathbf{V}$ & $\mathbf{S}$ & $\mathbf{V}$ & $\mathbf{L}$ & $\mathbf{T}$ & $\mathbf{I}$ & $\mathbf{V}$ & $\mathbf{A}$ & $\mathbf{F}$ & $\mathbf{S}$ & $\mathbf{M}$ & $\mathrm{E}$ & $\mathrm{R}$ & $\mathrm{F}$
\end{tabular} ctggccatctgtcatccattgcacctgtacaccatgtccggattgcagcgcceggttcgcatcattgccggcctctggatcgtcagtctc $\begin{array}{lllllllllllllllllllllllllllllll}\mathrm{L} & \mathrm{A} & \mathrm{I} & \mathrm{C} & \mathrm{H} & \mathrm{P} & \mathrm{L} & \mathrm{H} & \mathrm{L} & \mathrm{Y} & \mathrm{T} & \mathrm{M} & \mathrm{S} & \mathrm{G} & \mathrm{L} & \mathrm{Q} & \mathrm{R} & \mathrm{P} & \mathrm{V} & \mathrm{R} & \mathbf{I} & \mathbf{I} & \mathbf{A} & \mathbf{G} & \mathbf{L} & \mathbf{W} & \mathbf{I} & \mathbf{V} & \mathbf{S} & \mathbf{L} & \mathbf{3}\end{array}$ ttcagcgcagtgcctttcgccgtgttcaccgatatcgattacattctctacccaccgacccaagagaaatcgaggactcggctttctgt $\begin{array}{lllllllllllllllllllllllllllllllllll}\mathbf{F} & \mathbf{S} & \mathbf{A} & \mathbf{V} & \mathbf{P} & \mathbf{F} & \mathbf{A} & \mathbf{V} & \mathbf{F} & \mathrm{T} & \mathrm{D} & \mathrm{I} & \mathrm{D} & \mathrm{Y} & \mathrm{I} & \mathrm{L} & \mathrm{Y} & \mathrm{P} & \mathrm{P} & \mathrm{T} & \mathrm{Q} & \mathrm{E} & \mathrm{K} & \mathrm{I} & \mathrm{E} & \mathrm{D} & \mathrm{S} & \mathrm{A} & \mathrm{F} & \mathrm{C}\end{array}$ gcgatgcttagcaatccggaaggaattcccetgtgggagctgtcgacatgcctgtttttcgccgggccgatggtggtgatgattgtactc $\begin{array}{lllllllllllllllllllllllllllllll}\mathrm{A} & \mathrm{M} & \mathrm{L} & \mathrm{S} & \mathrm{N} & \mathrm{P} & \mathrm{E} & \mathrm{G} & \mathrm{I} & \mathrm{P} & \mathrm{L} & \mathrm{W} & \mathrm{E} & \mathbf{L} & \mathbf{S} & \mathbf{T} & \mathbf{C} & \mathbf{L} & \mathbf{F} & \mathbf{F} & \mathbf{A} & \mathbf{G} & \mathbf{P} & \mathbf{M} & \mathbf{V} & \mathbf{V} & \mathbf{M} & \mathbf{I} & \mathbf{V} & \mathbf{L} & 3\end{array}$ tacggccggatgggaatgcaaatccgctcccgaacgcaacgaaccgaggaactgggggtgcgaaatggttccattaacggtcctaaggta $\begin{array}{lllllllllllllllllllllllllllllllllll}\mathbf{Y} & \mathbf{G} & \mathrm{R} & \mathrm{M} & \mathrm{G} & \mathrm{M} & \mathrm{Q} & \mathrm{I} & \mathrm{R} & \mathrm{S} & \mathrm{R} & \mathrm{T} & \mathrm{Q} & \mathrm{R} & \mathrm{T} & \mathrm{E} & \mathrm{E} & \mathrm{L} & \mathrm{G} & \mathrm{V} & \mathrm{R} & \mathrm{N} & \mathrm{G} & \mathrm{S} & \mathrm{I} & \mathrm{N} & \mathrm{G} & \mathrm{P} & \mathrm{K} & \mathrm{V}\end{array}$ tctcagtcgaaaaaggcgattatccggatgctagctgccgttgtgataacgttctttgtgtgctgggcgccgtttcacgcccagaggttg

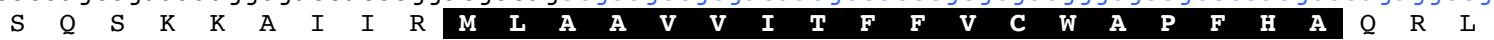
ctctttctgtacgcgcgggactggcaacacttcaacacggtcaatacgtggctgttttccgtcgcgggatggctgtactacgtttcgtgc

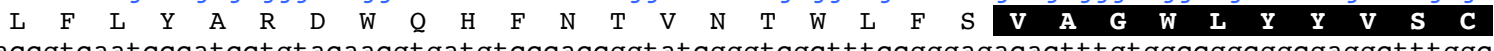
accgtcaatcccatcctgtacaacgtgatgtcccaccggtatcgggtcgctttccgggagacactttgtggccggcggcgaggctttggc $\begin{array}{llllllllllllllllllllllllllllllll}\mathbf{T} & \mathbf{V} & \mathbf{N} & \mathbf{P} & \mathbf{I} & \mathbf{L} & \mathbf{Y} & \mathbf{N} & \mathbf{V} & \mathrm{M} & \mathrm{S} & \mathrm{H} & \mathrm{R} & \mathrm{Y} & \mathrm{R} & \mathrm{V} & \mathrm{A} & \mathrm{F} & \mathrm{R} & \mathrm{E} & \mathrm{T} & \mathrm{L} & \mathrm{C} & \mathrm{G} & \mathrm{R} & \mathrm{R} & \mathrm{R} & \mathrm{G} & \mathrm{F} & \mathrm{G} & 4\end{array}$ accagctttgcgcgggatcaatcgagcttccgcgaaacgacggttgacgtgaacctgggctgcgagagctccaagctgctccgggctcga

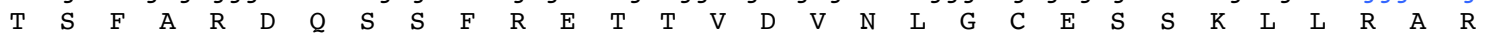
tcgatgatgcaatctagcaaacggtcccgctacaaggcgctctctacacgtccaacagcgtgcgatacagtggcgaccattacatccgg

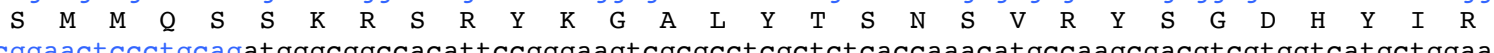
cggaactccctgcagatgggcggccacattccgggaagtcgcgcctcgctctcaccaaacatgccaagcgacgtcgtggtcatgctggaa

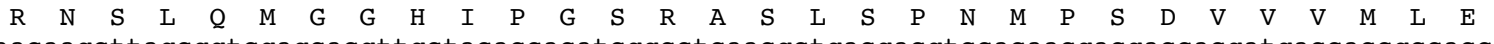
aacaagcttagcggtcgagcacgttgctacaccacatcggcctcaacgctgacgacgtccacaacgacgaccacgatgaccaccgccacc $\begin{array}{lllllllllllllllllllllllllllllllllll}N & K & L & S & G & R & A & R & C & Y & T & T & S & A & S & T & L & T & T & S & T & T & T & T & T & M & T & T & A & T\end{array}$ accggggaaacatcctcaaggtacccctgataagcatcaacggtggcacgggctgtctcgtcaacaataatgtaaatagcatcaacaac

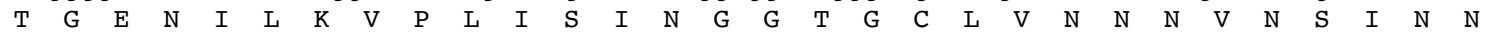
aactccaccaataacgccatcattcccaccgacaacagcaacaacatcaaccgtagcattagcaaggaaacaacctttccaacgcatcc $\begin{array}{lllllllllllllllllllllllllllllllllll}\mathrm{N} & \mathrm{S} & \mathrm{T} & \mathrm{N} & \mathrm{N} & \mathrm{A} & \mathrm{I} & \mathrm{I} & \mathrm{P} & \mathrm{T} & \mathrm{D} & \mathrm{N} & \mathrm{S} & \mathrm{N} & \mathrm{N} & \mathrm{I} & \mathrm{N} & \mathrm{R} & \mathrm{S} & \mathrm{I} & \mathrm{S} & \mathrm{K} & \mathrm{E} & \mathrm{N} & \mathrm{N} & \mathrm{L} & \mathrm{S} & \mathrm{N} & \mathrm{A} & \mathrm{S}\end{array}$ accccggttccgtcttcccgggcgtcgaccagcagcctgtcaatcgaaatggcactcgataccagcagcaaacaaccgccacctaaccgg $\begin{array}{lllllllllllllllllllllllllllllllll}T & P & V & P & S & S & R & A & S & T & S & S & L & S & I & E & M & A & L & D & T & S & S & K & Q & P & P & P & N & R\end{array}$ aacgacttatccctgtctgaccgaacagacagcaacgattcccaccagcaccatcctcaacagcatcccaatcctaatcatcaattaatt

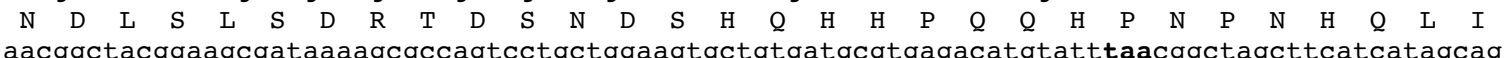

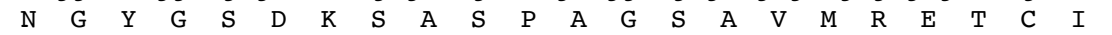
ccaccaccgaggcctccgctaaacaggatgacaacgaccccaagaatagccgcatggtcagctcagtatcgaggaatgaaacccgaagcg acaagccgttaaagcttgctctgcttcaattatagatattgctgcaacgtgataagatggctcgcaacggcgtatcgtcgtcgtgccgat tagtcgatatgagtaaaargagcgggaaatgtcgcaatgaaaattgaaaaaacttttacgttcaacgttccgtcatcggaatcatcga acttcaaagcagtttttatgttcaaaactattattcgatgaaaatgtgttcactgtggttcgtttggacaatagaataaagtgatcata tttecta $a_{(n)}$

3150

3240

3330

3420

B

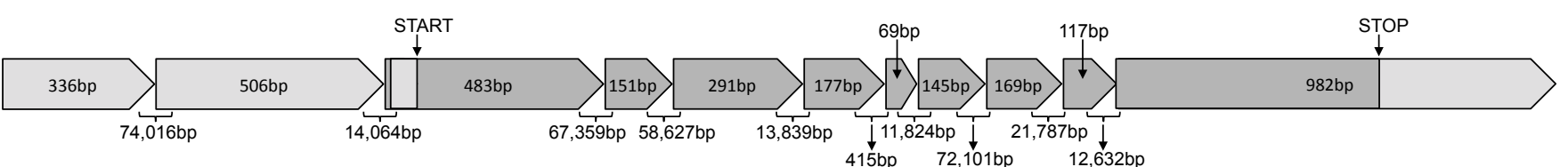




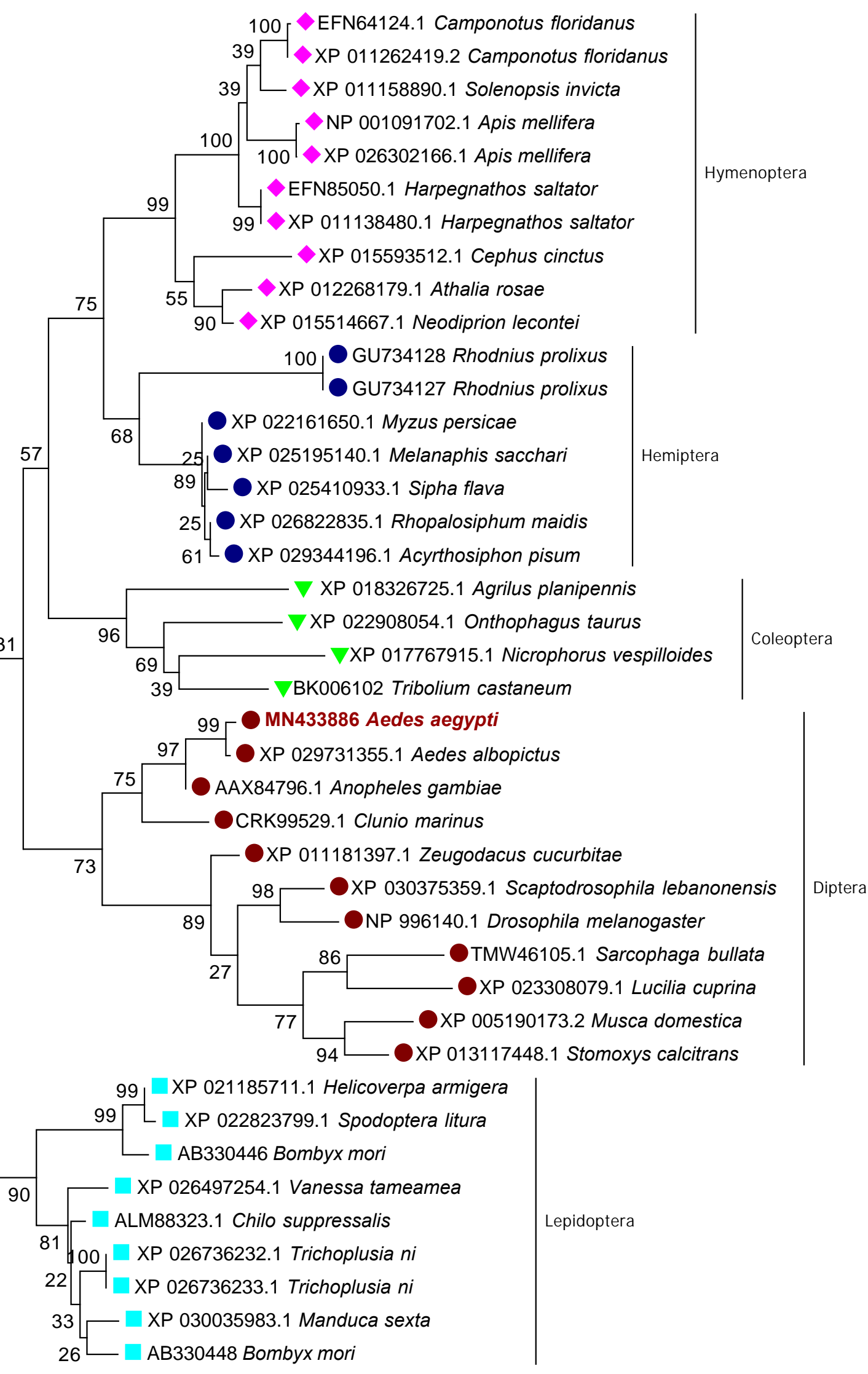


A

B 
A

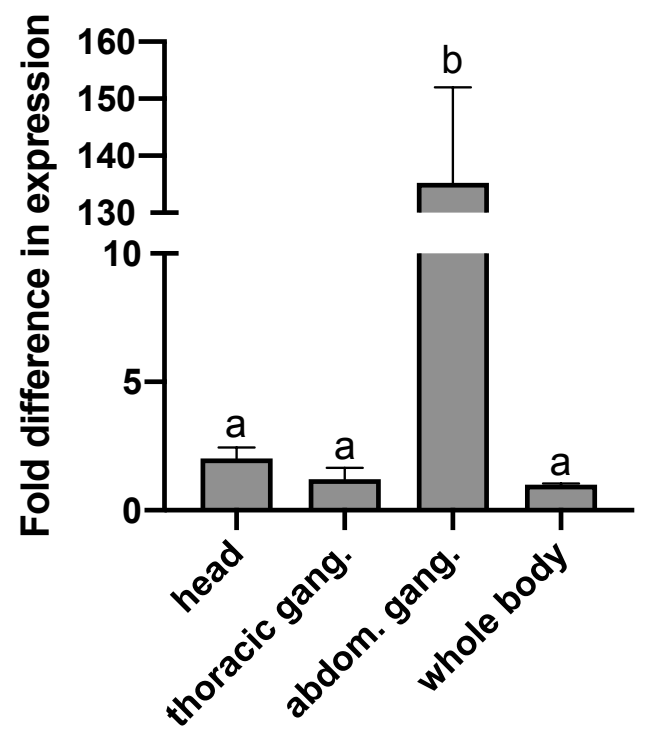

B

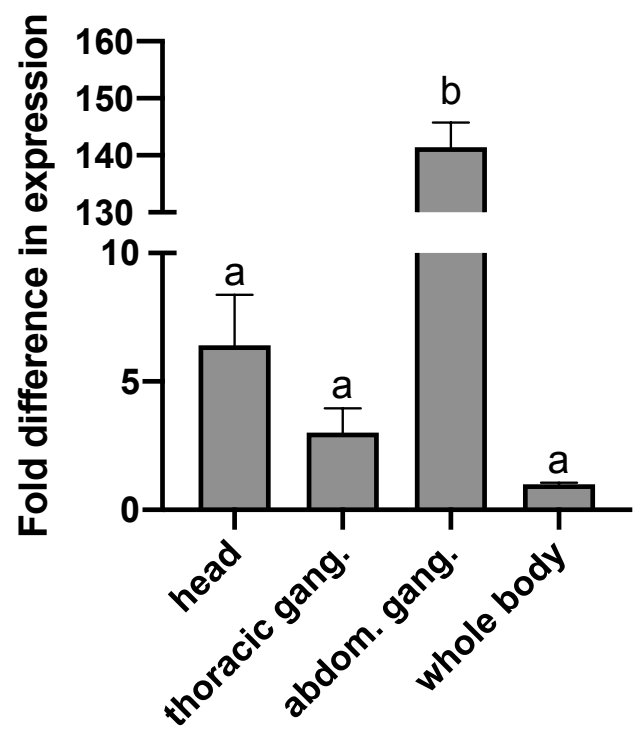

